\title{
Wave- and current-induced bottom shear stress distribution in the Gulf of Lions
}

\author{
François Dufois ${ }^{\mathrm{a}, \mathrm{b}, \mathrm{c},{ }^{*}}$, Pierre Garreau ${ }^{\mathrm{a}}$, Pierre Le Hir ${ }^{\mathrm{a}}$ and Philippe Forget ${ }^{\mathrm{c}}$ \\ a IFREMER, DYNECO/PHYSED, Centre de Brest, BP 70, 29280 Plouzané, France \\ b IRSN, DEI/SESURE, LERCM, Centre Ifremer, BP 330, 83507 La Seyne sur Mer, France \\ c LSEET-LEPI, UMR 6017, CNRS-USTV, BP132, 83957 La Garde, France \\ *: Corresponding author : Dufois F., Tel.: +33 298224760; fax: +33 298224864, email address : \\ Francois.Dufois@ifremer.fr
}

\begin{abstract}
:
Simulations of both currents and waves were performed throughout the year 2001 to assess the relative contribution of each to their overall erosive potential on the Gulf of Lions shelf. Statistical analysis of bottom shear stress (BSS) was compared to sediment grain-size distribution on the bottom. The hydrodynamic features of the bottom layer coincide with the distribution of surficial sediments, and three areas with different hydro-sedimentary characteristics were revealed. (i) The sandy inner shelf $(<30 \mathrm{~m})$ area is a high-energy-wave dominated area but may be subjected to intense current-induced BSS during on-shore winds along the coast and during continental winds mainly in the up-welling cells. (ii) The middle shelf (30-100 m) is a low-energy environment characterised by deposition of cohesive sediments, where the wave effect decreases with depth and current-induced BSS cannot reach the critical value for erosion of fine-grained sediments. (iii) The outer shelf, which has a higher bottom sand fraction than the middle shelf, may be affected by strong south-westward currents generated by on-shore winds, which can have an erosive effect on the fine-grained sediments.
\end{abstract}

Particular attention was paid to features of the current that were found to be predominant on the midouter shelf. These currents are strongly dependent on wind direction.

Keywords: Sediment transport; Bottom shear stress; 3D modelling; Gulf of Lions 


\section{$\underline{\text { Introduction }}$}

Studies on the dispersion and accumulation of sediment from rivers to continental margins have mostly been devoted to the continental shelves of open oceans affected by energetic swells and tides and by large rivers, such as the Pacific and Atlantic coasts of North America (Drake and Cacchione, 1985; Lyne et al., 1990; Wiberg et al., 1994). In Harris and Wiberg (2002), the authors used a sediment transport model to illustrate the effect of hydrodynamics on bed properties over narrow and wide continental shelf. According to their academic modelling, cross-shelf gradient in bed shear stress (due to decrease in wave-orbital velocities with water depth) has several implications on the transport, deposition and sorting of sediment depending on the steepness of the shelf. In their study, strong links between presentday hydrodynamics and sedimentological settings are exhibited. As the Mediterranean Sea is a micro-tidal, low-energy system, the dominant hydrodynamic forcings of Mediterranean shelves are likely to be different from that of shelves controlled by tides and swells. At a local scale, storm-generated wave effect on coastal sediment resuspension has been emphasised by several studies on the margin of the Gulf of Lions (GoL) (Ferre et al., 2005; Guillén et al., 2006) and on other margins of the north-western Mediterranean such as the Ebro margin (Puig et al., 2001; Guillén et al., 2002; Palanques et al., 2002). Nevertheless, the respective effect of waves and current on the whole shelf has not been fully studied. Thus, the objective of our study is to assess the potential impact of the wave- and current-induced bottom shear stress on the sediment dynamics and bed properties at a regional scale in the Gulf of Lions.

In their description of surficial deposits on the GoL, Got and Aloisi (1990) reported a sandy area near the coast, a sandy/muddy area near the slope and a mud band on the middle shelf. Although waves are assumed to be the main forcing that influences the sandy inner shelf (Ferre et al., 2005; Guillén et al., 2006), the presence of sand on the outer shelf has not been clearly explained. Most authors consider the offshore sands present in the outer shelf as relict 
features (Monaco, 1971; Aloisi, 1986; Berné et al., 1998). According to these authors, only transgressive processes would have been able to rework sediments when the sea level was lower by about $100 \mathrm{~m}$. However, recent studies demonstrated that a mobile carpet of sand is periodically active at the shelf edge (Bassetti et al., 2006). Schaaff $(2002 ; 2003)$ also showed that the surficial sediment over the shelf presents low critical shear stress corresponding to a fluffy layer that could easily be reworked.

Knowledge of wave- and current-induced bottom shear stress is thus necessary to understand sediment dynamics and bottom properties. At a local scale, this can be achieved by direct measurements. In the GoL, measurements of waves and currents have been made at the canyon head and inner-shelf stations (Canals et al., 2006; Guillén et al., 2006; Heussner et al., 2006; Palanques et al., 2006; Bourrin et al., this issue). However, only modelling can provide relevant information at both regional and long-time scales.

In combination with data analysis, modelling has recently improved our understanding of the high temporal and spatial variability of the circulation in the GoL (Estournel et al., 2003; André et al., 2005; Petrenko et al., 2005; Langlais, 2007). These studies were mainly devoted to surface circulation and mean transport, but were not sufficiently focused on bottom processes to improve our understanding of dynamic sediment processes. More recently, Ulses et al.(this issue) and Ferré et al. (this issue) developed a sediment transport model of the GoL and showed the influence of strong storms, dense water cascading, and even of bottom trawling on sediment dynamics on the shelf. They thus mainly studied the impact of episodic events.

The aim of this article is to present statistics for near bed hydrodynamics, and to consider their consequences for sediment transport, using a modelling approach. A one-year analysis of bottom shear stress (BSS) is presented. The respective influences of currents and waves are discussed and specific relationship between current-induced BSS and wind direction is analysed in more detail. Simultaneously, an application to this study is presented in order to clarify the link between the main physical processes and grain-size distribution of surficial 
sediments on the GoL shelf. The consequences of BSS distribution for sediment mobilisation are discussed along with possible consequences for sediment distribution.

\section{Regional setting}

\subsection{Hydrodynamics}

The GoL is hydrodynamically complex as several intense and strongly varying processes coexist (Figure 1). Millot (1990) described the main hydrodynamic processes: a) the general south-westward circulation along the slope, called the Northern Current; b) wind-induced currents; and c) the formation of dense water both on the shelf and offshore.

The geostrophic Northern Current is the northern branch of the general cyclonic circulation in the western Mediterranean basin. This current, whose core is several hundred meters thick, occasionally intrudes on the shelf (Petrenko, 2003) and displays seasonal variability. Mesoscale instabilities occur mainly during spring and winter when the water flux of the along-slope current is maximum (Flexas et al., 2002; Albérola and Millot, 2003; André et al., this issue).

Even if these instabilities can affect circulation on the shelf itself (Petrenko, 2003), the shelf is essentially forced by winds and by buoyancy discharge from the Rhone River. Estournel et al. (2003) described the influence of northern and north-western winds, whereas Ulses et al. (in press) focused on the influence of E-SE winds. Intense and frequent continental winds (the Mistral in the eastern part of the GoL and the Tramontane in the western part) (Millot, 1990) push the surface waters off shore and induce local upwelling. On-shore winds (mainly eastern and south-eastern winds), which are less frequent (Millot, 1990), result in the accumulation of water on the coast and the downwelling of surface water. These winds can be very strong and appear or disappear very suddenly, and thus generate Kelvin waves (Crepon and Richez, 1982) or inertial oscillations, which mainly occur during stratified 
conditions (Millot and Crepon, 1981; Petrenko et al., 2005). Cold and dry continental winds that appear during wintertime are also likely to generate dense water on the shelf. This dense water, which is preferentially formed on the western part of the shelf, dives on the southwestern end part of the shelf resulting in dense water cascading through the canyon (DufauJulliand et al., 2004).

Freshwater input, an important forcing factor on the shelf (Gatti et al., 2006), is mainly controlled by the Rhone River, which is the largest source of freshwater in the Mediterranean Sea with $92 \%$ of the input in the GoL (Bourrin and Durrieu de Madron, 2006). The Rhone River has two functional branches: the Grand Rhone which is responsible for about $90 \%$ of the discharge, and the narrower Petit Rhone. Its impact on shelf dynamics can be observed far from the river mouth (Gatti et al., 2006) and is very dependent on the wind regime.

\subsection{Sediments}

The Rhone River is also a significant forcing with respect to sediment dynamics as it is responsible for about $94 \%$ of total solid discharge into the GoL (Bourrin and Durrieu de Madron, 2006). Thus the sedimentological setting of the shelf, previously described by Got and Aloisi (1990), is mainly controlled by solid discharge from the Rhone River and by hydrodynamic processes (waves and currents).

In the present study, recent laser grain-size analyses of surficial sediment cores were used to generate a new sediment distribution map. Data from different projects, i.e. REMOTRANS (Miralles et al., 2005; Roussiez et al., 2005a; Roussiez et al., 2005b; Roussiez et al., 2006; Lansard et al., 2007), METROC, EUROSTRATAFORM (Miralles et al., 2006), REDITE, SEDIFOS, and from other sporadic campaigns were interpolated over the shelf. Interpolation was limited to the $160 \mathrm{~m}$ isobath as it coincides with the beginning of the high bathymetric gradient. Figure 2a is a map of the sand fraction (sediment fraction greater than $63 \mu \mathrm{m}$ ). To compare the new map with the well-known sedimentologic characteristics of the surficial deposits on the shelf (Got and Aloisi, 1990), a map of the non-pelitic fraction ( $>40 \mu \mathrm{m}$ ) was 
redrawn from CEFREM data acquired between 1970 and 1990 (Figure 2b). The sediment distribution on this latter map (which contains some Got and Aloisi data, i.e. data acquired before 1980, and some others) is very similar to the distribution described by Got and Aloisi. However, we did not compile the two data sets because the method for determining surficial grain size has changed. The new sediment distribution is based on cores collected with corers that preserve the interface satisfactorily even in areas with cohesive sediment. Grain-size analysis was conducted using laser measurements. The distribution of the stations is relatively poor compared to the one used to obtain CEFREM map (figure 2b). The old data came from cores obtained with corers that may have reworked the interface and/or the finest particles may have been ejected from the corer (all the more since the stations were deep). In addition, the method used for grain size analyses was quite different from the new laser methods. The two maps are thus complementary. In fact, although the new distribution is based on more accurate data, these data are irregular due to the limited number of stations on the shelf. Actually, the new map is in agreement with the previously described sedimentologic setting. However, it should be noted that the new map shows a smaller fraction of coarse sediment on the outer shelf. It seems that the use of a corer that preserves the interface gives a muddier interface. Moreover, the fixed limit of coarse sediment is not the same in the two maps ( $40 \mu \mathrm{m}$ in the old one and $63 \mu \mathrm{m}$ in the new one) which could partially explain this difference. Nevertheless, the grain-size gradient between the middle shelf and the shelf break is still present with the new sediment distribution and this is not well explained.

Different sedimentary facies occur from the coastline to the slope. Indeed, the inner shelf ( 0 to $30 \mathrm{~m}$ ) consists of a sandy band, followed by a muddy area on the middle shelf ( $\sim 30$ to $100 \mathrm{~m}$ ), and finally by a muddy-sandy area in the outer shelf. As sediments become cohesive when mud content exceeds 30 \% (Mitchener and Torfs, 1996; Panagiotopoulos et al., 1997; Le Hir et al., in press), only the inner-shelf bed appears to be covered by non-cohesive sediment. Conversely, the muddy-sandy area on the outer shelf should be cohesive. Close examination of the data suggests a representative (median) grain size generally comprised 
between 80 and $100 \mu \mathrm{m}$ for the inner-shelf whereas the middle shelf has a representative grain size of about 10 to $15 \mu \mathrm{m}$. The gradient from the middle shelf to the outer shelf is more progressive. The median grain size can reach about 30 to $40 \mu \mathrm{m}$ in the coarsest areas of the outer shelf.

Knowledge of critical shear stress is necessary to link sediment distribution and hydrodynamics. In the Gulf of Lions, the critical shear stress of erosion has been measured (Schaaff et al., 2002; Schaaff, 2003) in a flume at several stations across the shelf (cf. Figure $2 b)$. The critical shear stress of the surficial layer in cohesive areas ranges from 0.016 to $0.069 \mathrm{~N} / \mathrm{m}^{2}$ and is spatially and temporally variable. Actually, these results are close to frequent in-situ critical shear stress measurements over fluffy layer which range between 0.02 and $0.05 \mathrm{~N} / \mathrm{m}^{2}$ (Schaaff et al., 2002). According to Shields (in Soulsby, 1997) in a noncohesive area, the critical shear stress corresponding to a median grain size of between 80 and $100 \mu \mathrm{m}$ would be expected to be near $0.15 \mathrm{~N} / \mathrm{m}^{2}$.

Considering the previously described facies and the hydrodynamic processes acting on the bed, the question to be answered is whether these facies are relicts or if they are due to present day reworking.

\section{$\underline{\text { 2. Modelling approach }}$}

\subsection{Hydrodynamic model}

The hydrodynamic processes were modelled using the operational MARS-3D code (3D hydrodynamical Model for Applications at Regional Scale), a three-dimensional model with reduced $(\sigma)$ vertical coordinates based on the resolution of the Navier-Stokes equations (Lazure and Dumas, 2007, http://www.previmer.org). This model with free surface is inspired by the model of Blumberg and Mellor (1987) as primitive equations are solved using a timesplitting scheme under assumptions of Boussinesq approximation, hydrostatic equilibrium and incompressibility. The mode splitting technique was built with an iterative and semi- 
implicit method and allows simultaneous calculation of internal and external modes with the same time step. The external mode is solved with an ADI (Alternating Direction Implicit) scheme (Leendertse, 1970).

The vertical turbulent diffusion of momentum, heat, and salt is computed using the formulation of Pacanowsky and Philander (1981), which takes stratification into account through a local gradient Richardson number. For the horizontal turbulent diffusion, MARS3D uses Smagorinsky's formulation (1963).

Momentum, salt or heat advection is low-diffusive as the model uses a Quick scheme (Leonard, 1979). This scheme is replaced by an UPWIND scheme in the case of strong gradients.

The model is forced by atmospheric conditions (modelled wind field and solar fluxes provided by Météo-France ALADIN and ARPEGE models), daily Rhone River discharge, and lateral incoming fluxes (salt, momentum. and temperature) and elevations at the open boundaries.

The lateral fluxes and elevations at the open boundaries are deduced from a chain of nested MARS-3D models, for which the spatial resolution and the spatial extension differ (André et al., 2005). The highest resolution model (NORMED), simulating the Northern Basin (its southern open boundary is located at $39.5^{\circ} \mathrm{N}$ ) circulation with a horizontal resolution of $1.2 \mathrm{~km}$ and 30 vertical layers, was used for this study. NORMED was validated with temperatures from AVHRR imagery acquired in 2001 (André et al., 2005) and with in-situ data (surdrift buoys and hydrological measurements) acquired in 2005-2006 (André et al., this issue).

\subsection{Wave model}

Wave fields were modelled in the western Mediterranean Sea with a resolution of $0.1^{\circ}$ using the third generation wind-wave model WAVEWATCH-III (Tolman, 2002a) forced by Météo-France wind fields. 
This model, which was developed at NOAA/NCEP and inspired by the WAM model, has been successfully applied in global- and regional-scale studies in many areas throughout the world's oceans (Tolman, 2002b; Chu et al., 2004) and especially in the western Mediterranean Sea (Ardhuin et al., 2007). The model is based on the two-dimensional wave action balance equation including energy density generation and dissipation terms by wind, white-capping, wave-bottom interaction, and redistribution of wave energy due to wavewave interactions.

The model was validated and compared with other models for two periods in 2002 and 2003 (Ardhuin et al., 2007). In annex A, we present our own validation for the year 2001, (the year considered in this study) using measurements from two wave buoys in the GoL.

\subsection{Method used to calculate the BSS}

From the point of view of sediment dynamics, it is advisable to separate skin friction (which should be taken into consideration for sediment mobility) from total BSS (Dyer, 1980). Generally, the total current-induced BSS is obtained by measuring the velocity profile in the first metres above the sediment bed and fitting this profile with a logarithmic profile in agreement with the von Karman-Prandtl theory (Equation 4, annex B). When dealing with modelled currents, the method to calculate total BSS consists in assuming a logarithmic velocity profile in the first layer above the bottom. The formulation of the roughness parameter $\mathrm{z}_{0}$ depends on grain roughness and bed roughness (ripples). Usually, the method to calculate the skin friction, (hereafter called reference method) only uses grain roughness in the computation of $\mathrm{z}_{0}$ (Soulsby, 1997).

However it is recognized that bedforms, which influence the flow (and the total BSS) locally, are also likely to modify skin friction when the latter is computed with a current above the bottom boundary layer (Smith and McLean, 1977; Dyer, 1980; Li, 1994). This is the case in our computation of BSS from the modelled velocity at the first $\sigma$ level. Thus, the use of the 
reference method does not allow a good approximation of skin friction in the presence of ripples.

Here we calculate the skin friction for waves and currents using a boundary layer model based on the results of Smith and McLean (1977), and taking into account the bed ripples created by the waves. The computation of skin friction is performed in an iterative way consisting of the computation loop described in annex B. The method includes four steps:

- computation of roughness resulting from grains, from ripples, and from possible bedload;

- computation of total BSS due to both waves and currents;

- computation of skin friction from total BSS;

- ripple prediction, when the skin friction exceeds the threshold of sediment motion on noncohesive bed.

Considering that ripples can only be formed in a non-cohesive environment, in the case of cohesive sediment, the reference method is used. For application to the GoL, we consider that the sediment is non-cohesive only on the inner-shelf (depth $<30 \mathrm{~m}$ ), and is characterized by fine sands with an average diameter of $100 \mu \mathrm{m}$ (apart from the surf zone) in agreement with observations (cf. § 1.2). The cohesive sediment roughness $\mathrm{z}_{0}$ over the mid-outer shelf in areas deeper than $30 \mathrm{~m}$ was fixed at $0.1 \mathrm{~mm}$, which is a typical value found in the literature (Soulsby, 1997).

The impact of the computation of bed roughness can be considerable even in terms of skin friction: an example is given in annex C, where the wave-induced skin BSS is shown to vary in the order of $100 \%$ when ripples are taken into account. In addition, our method accounts for variations in bedforms over time, depending on the actual forcing and previously generated bedforms.

\subsection{Case study in the year 2001}


The previously described model was used to compute the BSS throughout the year 2001 from modelled currents and waves ( 1 output every 3 hours). 2001 can be considered as representative of the general climate of the region. Concerning the river outflows, during 2001, the Rhone River flux varied in the range of 577 to $6646 \mathrm{~m}^{3} / \mathrm{s}$ with an average value of $2077 \mathrm{~m}^{3} / \mathrm{s}$. With a mean river discharge of $1769 \mathrm{~m}^{3} / \mathrm{s}$ during the 1977-2004 period (Bourrin and Durrieu de Madron, 2006), the year 2001 presented an approximately $20 \%$ increase in flux. Moreover, both wind and wave histograms are in good agreement with the WWMEDATLAS (The Medatlas Group, 2004) climatology based on both modelling and observations between 1992 and 2002. A comparison between our yearly forcing conditions at location $42^{\circ} \mathrm{N}, 5^{\circ} \mathrm{E}$ (near the Météo-France Buoy, cf. Figure 1) and the 10-year climatology is illustrated by the histograms in Figure 3. Storm events or windy episodes in 2001 occurred with approximately the same frequency as in the climatology even though winds appeared to be somewhat stronger in 2001 , i.e. winds are stronger than $14 \mathrm{~m} / \mathrm{s}$ for $11.1 \%$ of the time ( 8.5 $\%$ for WW-MEDATLAS climatology), and waves higher than $5 \mathrm{~m}$ for $4.2 \%$ of the year (5.2 $\%$ for WW-MEDATLAS climatology). According to the climatology as well as to the 2001 statistics, wind and wave regimes were mostly north-western. The two other prevailing wave regimes were mainly eastern and south-western.

The distribution of wind and wave episodes in 2001 appears to fit fairly well with medium term observations. As these are the main forcing for BSS computation in the GoL, the year 2001 can be considered as representative of present day hydrodynamical forcing on the bed of the GoL shelf. This justifies producing BSS statistics from simulations throughout the year 2001 and analysing potential effects on the distribution and mobilisation of sediments.

\section{$\underline{\text { 3. Results }}$}

Hereafter BSS designates the skin friction component of total BSS. 


\subsection{One-year analysis of BSS}

As higher BSS conditions have the most impact on sediment dynamics, the BSS values were sorted at each grid point of the hydrodynamic model in order to quantify the distribution of the top $10 \%$ values. Thus, the map of the $90^{\text {th }}$ percentile (hereafter denoted BSS-P90) (Figure 4) was computed (the $p^{\text {th }}$ percentile is a value such that $p \%$ of the measurements are less than this value and $(100-p) \%$ are greater). The BSS-P90 presents an area of low values between 0.001 and $0.01 \mathrm{~N} / \mathrm{m}^{2}$ on the middle-shelf. The BSS-90 increases a little towards the shelf break (between 0.01 and $0.05 \mathrm{~N} / \mathrm{m}^{2}$ ) and much more towards the coast (from 0.01 to more than $1 \mathrm{~N} / \mathrm{m}^{2}$ on the inner-shelf). The $98^{\text {th }}$ percentile was also computed (data not presented here) and exhibited exactly the same structure with values about twice as high. Thus, from time to time, BSS exhibits relatively high values in comparison with critical shear stress that ranges from 0.016 to $0.069 \mathrm{~N} / \mathrm{m}^{2}$ over the cohesive part of the shelf. On the sandy inner shelf, BSS can be really high (all the more since the sea is shallow at this location) compared to the critical shear stress of find sand (about $0.15 \mathrm{~N} / \mathrm{m}^{2}$ ).

Statistics on wave- and current-induced BSS are qualitatively in good agreement with surficial sediment distribution (Figures 2 and 4). On the middle shelf, muddy areas are quite well correlated with areas of low BSS, whereas the inner shelf and the outer shelf correspond to the presence of a higher BSS-P90. Nevertheless some areas are not well correlated, such as the Bay of Marseille and one deep area in the middle of the outer shelf where the sand fraction does not correspond to a higher percentile. These specific discrepancies will be discussed later.

\subsection{Respective influences of currents and waves on BSS}

To understand the role played by waves and currents in sediment dynamics over the shelf, the respective contributions of waves or currents to the higher BSS (> BSS-P90) were determined (Figure 5). In 2001, when the BSS was high, waves appear to be the main 
contributor in coastal areas $(<30-40 \mathrm{~m})$. In the other parts of the shelf, the fact that BSS values were higher than BSS-P90 is mainly due to the influence of the current.

The results show that there is a marked difference in bottom dynamics between the inner shelf, which is wave-dominated, and the other parts of the shelf, which are more currentdominated. This explains a difference in the value of BSS-P90 of about one or two orders of magnitude between the sandy inner shelf and the other parts of the shelf.

\subsection{Wave-induced BSS}

Whereas waves are not expected to have an effect on the bed in deeper shelf areas, close to the isobath $100 \mathrm{~m}$ energetic sea states can occasionally have an influence. This is illustrated at point C (location shown in Figure 5) in Figure 6a which shows wave-induced BSS versus the mean wave direction. It should be noted that the majority of wave-induced BSS values over the year for this particular location are not displayed in Figure 6a, as they were very small $\left(<10^{-6} \mathrm{~N} \cdot \mathrm{m}^{-2}\right)$. A BSS of about $0.08 \mathrm{~N} \cdot \mathrm{m}^{-2}$ was observed during the biggest storm (significant wave height of about $5 \mathrm{~m}$ and peak period of approximately $12 \mathrm{~s}$ ). At this location, the most energetic sea states mainly propagate from the east, but northerly windwaves or south-westerly swells can also be energetic. Moreover the latter are remarkably directional. The most energetic sea states occur preferentially before a change in wind direction (from continental wind to eastern wind). The swell most often propagates from the Ligurian Sea before the arrival of the depression. Thus wave-induced BSS can be greater during continental wind episodes, even if they have been generated by eastern winds (Figure $6 \mathrm{a}$ and $6 \mathrm{~b})$. As a consequence, the correlation between swell and wind direction is low.

\subsection{Current-induced BSS}

In this section, we focus our attention on the influence of the currents themselves on the bottom layer. Indeed, currents appear to be an important forcing on the mid-outer shelf. 
Moreover, even if waves are predominant on the inner shelf, only currents are likely to transport the sediment. Statistical knowledge of current patterns in the bottom layer is thus necessary to understand both resuspension and sediment transport processes on the shelf. Before examining the statistics of current-induced BSS in the GoL, it is important to characterise the flow patterns of prevailing high-wind regimes.

\subsubsection{Mean features of current-induced BSS}

In order to determine schematic bottom circulation patterns, an analysis based on wind direction $\left(\mathrm{W}_{\mathrm{dir}}\right)$ was performed. Winds were divided into two sectors: off-shore winds $\left(\mathrm{W}_{\mathrm{dir}}<45^{\circ}\right.$ or $\left.\mathrm{W}_{\mathrm{dir}}>225^{\circ}\right)$ and on-shore winds $\left(45^{\circ}<\mathrm{W}_{\mathrm{dir}}<225^{\circ}\right)$. During 2001, the mean (over time) current-induced BSS vector was calculated at each grid point when wind was well established (winds $>5 \mathrm{~m} \cdot \mathrm{s}^{-1}$ ) for events corresponding either to on-shore or off-shore winds. These two resulting fields of mean current-induced BSS vectors are both presented on Figure 7 (arrows). In order to determine whether the mean BSS patterns in response to off-shore or on-shore winds is significant or not, the ratio (R) between the intensity of the mean BSS vector and the mean intensity of the BSS over the same time is also presented on Figure 7 (grey scale). If we note $\vec{\tau}(t)$ the BSS vector at the time t, the mean BSS vector over time is noted $\vec{\tau}_{m}=\langle\vec{\tau}(t)\rangle^{t} . \quad \theta$ being the angle between $\vec{\tau}(t)$ and $\vec{\tau}_{m}$, we obtain $\left\|\tau_{m}\right\|=\langle\|\tau(t)\| \cos (\theta)\rangle^{t}$. Then, $R=\frac{\left\|\tau_{m}\right\|}{\langle\|\tau(t)\|\rangle^{t}}=\frac{\langle\|\tau(t)\| \cos (\theta)\rangle^{t}}{\langle\|\tau(t)\|\rangle^{t}}$. Thus, $\mathrm{R}$ is a parameter that quantifies the unidirectionality of the BSS vector over time. If R is close to 1 , the variation in BSS direction is weak, and the direction of the mean vector is representative of the considered wind sector. On the contrary, if R is close to 0 , the variation in BSS direction is strong, and the mean vector is not representative. 
In case of on-shore winds (from the sea), the response in terms of BSS direction is nearly unidirectional during 2001 on the major parts of the shelf ( $\mathrm{R}$ is almost everywhere greater than 0.5 ) whatever the specificity of the on-shore wind event. In fact, an intense coastal jet quickly starts up over the whole water column and main currents are directed towards the west/south-west. When considering the bottom BSS patterns induced by off-shore winds (continental winds) it appears that BSS are nearly unidirectional for 2001 in the costal zone where up-welling cells have been identified. On the middle shelf, a representative recirculation cell appears whatever the off-shore wind situation, whereas the rest of the shelf, including the inner shelf area on the south-west (along the Roussillon coast), does not display any significant BSS pattern. This means that the response to established off-shore wind is relatively dispersed in direction and thus it is not possible to give a unique scheme for all cases on the whole shelf. These results are coherent with those of Estournel et al (2003) who showed that off-shore winds generate mean (depth-averaged) circulation highly dependent on the direction and the spatial distribution of these winds.

\subsubsection{Statistical analysis of current-induced BSS}

In order to determine the origin of current-induced BSS $\left(\tau_{c}\right)$ able to resuspend fine-grained sediment on the shelf (i.e. when $\tau_{\mathrm{c}}>\tau_{\mathrm{cr}}$ ), a statistical analysis based on wind direction was performed. The probability of BSS being higher than critical shear stress $\left(\tau_{\mathrm{cr}}\right)$ due to local offshore winds $\left(\mathrm{W}_{\mathrm{dir}}<45^{\circ}\right.$ or $\left.\mathrm{W}_{\mathrm{dir}}>225^{\circ}\right)$ or to local on-shore winds $\left(45^{\circ}<\mathrm{W}_{\mathrm{dir}}<225^{\circ}\right)$ was calculated. The probability $\mathrm{P}$ plotted in Figure 8 is then the probability that $\tau_{\mathrm{c}}>\tau_{\mathrm{cr}}$ and $45^{\circ}<\mathrm{W}_{\mathrm{dir}}<225^{\circ}$ with the critical value chosen equal to $0.04 \mathrm{~N} \cdot \mathrm{m}^{-2}$. This value corresponds to a representative critical BSS of erosion observed by Schaaff $(2002 ; 2003)$ on the very surficial layer of fine sediment over the shelf of the GoL. This is a simplified approach that considers only one critical BSS for the entire shelf, but modelling performed by Schaaff (2003) demonstrates that the value of $0.04 \mathrm{~N} \cdot \mathrm{m}^{-2}$ is coherent for the entire cohesive area of the shelf. 
In Figure 8, P appears as a dark area where high BSS occurs mainly during off-shore winds, whereas the bright area shows where high BSS occurs mainly during on-shore winds. On the middle shelf, current-induced BSS never reaches the chosen critical value as the currents are too weak. It appears that the outer shelf (next to the slope, circle C) is mainly subjected to intense currents during stormy on-shore wind episodes (bright area). Nevertheless, the probability of occurrence is low, in the order of $0.2 \%$ (of the time during 2001). On the inner shelf, on-shore winds influence a bigger area (farther from the shore) even if both wind regimes are able to mobilise bottom particles. In front of the Petit Rhone (black area, circle A), BSS is statistically strong mainly during off-shore wind regimes (Mistral and Tramontane) and a BSS higher than $0.04 \mathrm{~N} \cdot \mathrm{m}^{-2}$ appears more than $1 \%$ of the time. This location corresponds to a well-known up-welling cell caused by this wind regime (Millot, 1990).

We now discuss zones A, B and C in more detail. At these locations, the high BSS values are quite polarised and flow predominantly alongshore. Moreover, their directions are directly linked to wind direction (Figure 9). The BSS induced by on-shore winds (in red, Figure 9) and those induced by off-shore winds (in blue) are nearly unidirectional and occur in opposite directions. Such polarisation is partly due to bathymetry. However, this remark is not valid for the whole shelf, as shown by Figure 7.

Close to the slope $(\mathrm{C})$, in agreement with the previous analysis, maximum BSS directed towards the south-west is generated by on-shore winds, which are weaker in intensity and less frequent than winds of continental origin (Figures 3 and $6 \mathrm{c}$ ). The two other sites, which are located closer to the coast, are relatively symmetric: rather high BSS is observed for various wind directions although the statistic is quite different.

Furthermore, there is no definite relationship between the local wind intensity alone and the intensity of BSS. For example, at location C, eastern winds of lower intensity are able to generate BSS that is at least as high as that generated by continental winds or south-western winds (the high BSS represented by a big black dot in Figure 6d corresponds to a medium intensity eastern wind, also represented by a big dot in Figure 6c). 


\section{Discussion}

On the outer shelf, which is current dominated (Figure 5), the surficial sediment has a low fine particle content. The strongest currents in the area are south-westward and are generated during periods of on-shore winds (mainly eastern) (Figure 8). The thickness of fine sediment that can be eroded during these rare episodes of eastern winds can be estimated by assuming some characteristics of its erodability. Considering the often used Partheniades (1962) erosion law ( $\mathrm{E}=\mathrm{E}_{0}\left(\tau / \tau_{\mathrm{cr}}-1\right)\left[\mathrm{Kg} . \mathrm{m}^{2} . \mathrm{s}-1\right]$ if $\left.\tau>\tau_{\text {cr }}\right)$ with $\mathrm{E}_{0}$ ranging from $10^{-5}$ to $10^{-3}$ Kg. $\mathrm{m}^{-2} \cdot \mathrm{s}^{-1}$ (Whitehouse et al., 2000) for a non-consolidated sediment (concentration of about $500 \mathrm{Kg} \cdot \mathrm{m}^{-3}$ ), the erosion rate of fine sediment (with $\tau_{\mathrm{cr}}=0.04 \mathrm{~N} \cdot \mathrm{m}^{-2}$ ) was calculated for the whole shelf for 2001. At point C located on the outer shelf, the erosion, which appears entirely during on-shore winds, ranges from $0.9 \mathrm{~mm} /$ year to $9 \mathrm{~cm} /$ year. On the other hand, the order of magnitude of deposition should not exceed the apparent sedimentation rate (ASR) observed in this area. Thus net deposition is maximized by observed ASR in the area, which has been estimated to be in the order of $1 \mathrm{~mm} /$ year from ${ }^{210} \mathrm{~Pb}$ core dating (Miralles et al., 2005). On most of the outer shelf, $\tau_{\mathrm{cr}}$ for surficial fine sediment is exceeded slightly more than $0.2 \%$ of the time (cf. Figure 8 with $\tau_{\mathrm{cr}}=0.04 \mathrm{~N} \cdot \mathrm{m}^{-2}$ ) and the erosion of sediment may compensate for the supply of fine sediment. Nevertheless, as BSS values never exceed the critical shear stress value for fine sands $\left(0.1 \mathrm{~N} . \mathrm{m}^{-2}\right)$ on the outer shelf, the fine sand could not be eroded and the sediment should consequently not be reworked deeply. Only the nonconsolidated surface of the sediment may be affected by currents flowing south-westward. Thus, eastern storms are able to sweep the recent fine sediment deposits away and the sandy interface may be conserved. In fact, high BSS is not required to explain sandy beds. BSS just higher than the critical shear stress of non-consolidated fine sediment may be sufficient to explain why recently supplied fine sediments do not remain on the bed. 
In some places, the sand fraction features do not appear to agree with computed hydrodynamical forcings and this may partly be explained by the limits of this study.

Recent studies have demonstrated that the process of cold, dense water cascading is able to resuspend sediments from the shelf and to transport them towards the canyons (Palanques et al., 2006; Ulses, 2006; Bourrin et al., this issue; Ulses et al., this issue). The formation of dense water is taken into account in our model and in the computation of the BSS statistics, but its influence is not obvious. Both the intrusions of the Northern Current and the formation of dense water are subject to high inter-annual variability (Guarracino et al., 2006; Langlais, 2007) and, from this point of view, statistics covering only one year may be not sufficient to quantify the processes. Actually, it appears that the year 2001, which was selected as being representative for wind and wave effects, did not undergo intense and/or frequent episodes of dense water formation (Heussner et al., 2006): this feature appears to be a limiting factor of this study. A statistic built with a multi-year model would be useful to investigate the effect of these very variable processes.

Moreover, the Northern Current occasionally intrudes on the shelf (Petrenko, 2003) but its influence on the bed was not shown in our modelling. The simulated Northern Current seems to flow a little too far from the shelf break, and its intrusion is thus likely to be underestimated. These intrusions may have a local effect on the outer-shelf bed, but probably not on the entire outer shelf. Thus the sandy area in the middle of the outer shelf may be impacted by the Northern Current, although the computed BSS remains low. This may explain why, in the middle of the outer shelf, the BSS seems rather low whereas at the surface, the sand fraction reaches almost $40 \%$ (Figure $2 a$ ). In the same way, in the sandy southern part of the bay of Marseille, underestimation of the simulated Northern Current intrusions may also be responsible for underestimation of the BSS statistic.

In addition, other factors than hydrodynamic forcings are likely to explain grain size distribution. The supply of fine sediment, which is linked to the proximity of the mouth of the Rhone River, also contributes shaping the shelf bed: a reduction of the fine sediment fraction 
can thus be expected with an increase in the distance from the source. This would explain why the fine fraction on the outer shelf between $3.5^{\circ} \mathrm{E}$ and $4.5^{\circ} \mathrm{E}$ is lower than that between $4.5^{\circ} \mathrm{E}$ and $5^{\circ} \mathrm{E}$. Also, the bay of Marseille is a rather low-energy but sandy area. In the eastern part of the GoL, the lack of fine particles in the surficial sediment could be related to a smaller supply of fine sediments: actually, the Rhone river discharge is mainly dispersed south-westward, and no other source of fine particles has been observed upstream of the eastern part of the GoL shelf, as water depths increase very fast in this area. We also suggest that the proximity of the slope may have an impact on the net balance of the fine sediment. When erosion occurs on the shelf, the closer to the shelf break the fine particles are located, the more likely they are to be removed from the shelf. This remark is valid for the entire outer shelf. The combined effects of the hydrodynamic intensity, the distance from the source of sediment and the proximity of the slope, which plays the role of a sink for sediments, likely explain the slight increase in grain size on the outer shelf.

\section{Conclusions}

In this work we combined the use of wave and current models, and computed the realistic variation of the BSS distribution over a period of one year, in order to analyse the main physical processes that act on the bed. The BSS model, which allows prediction of ripple formation, was developed in order to take into account the effect of bedform roughness on skin friction over a non-cohesive bed. The skin friction component of the total BSS was consequently calculated at both annual and regional scales in the GoL in order to focus on sediment dynamics.

Particular attention was paid to currents, which were found to be the main forcing in the midouter shelf. A relationship between wind direction and the intensity and direction of BSS can be deduced. The analysis conducted throughout 2001 shows that significant bottom currents are almost "channelled" and flow predominantly alongshore on the inner-shelf both during 
on-shore and off-shore winds. Moreover, the response in terms of BSS directions is nearly similar whatever the on-shore wind conditions all over the shelf, with south-westward water flux. The BSS pattern in response to off-shore winds is less schematic and important fluctuations in direction may appear on a large part of the mid-outer shelf. This study also demonstrated the importance of on-shore winds, which induce simultaneously erosion and transport over most of the shelf, especially when a swell generated during the same storms is superimposed. Continental winds only show erosive potential in coastal areas and preferentially in the up-welling cells. However, these winds are generally associated with waves of low amplitude and are probably not the major forcing mechanism of erosion on the shelf, except in the current-dominated deeper part of the up-welling cells.

The one-year analysis of the BSS characteristics using a modelling approach allowed us to highlight the strong link that exists between bed characteristics and present-day hydrodynamic structures. Hydrodynamic features coincide with sediment surficial distribution and three areas with different characteristics were revealed:

(i) Near the shore $(<30 \mathrm{~m})$ sandy areas correspond to high-energy areas dominated by waves. In addition, the inner shelf may be subject to intense currents near the bottom which are able to erode or transport fine particles resuspended by waves, both during continental and on-shore wind conditions.

(ii) On the middle shelf ( 30 to $100 \mathrm{~m}$ ), the contribution of waves decreases progressively with depth. This muddy area presents the lowest $90^{\text {th }}$ percentile of BSS of the whole shelf. Current-induced BSS never reaches the representative critical value for erosion, evaluated from erodability measurements. In this area, even if wave-induced BSS may very occasionally erode fine sediments (wave-induced BSS is slightly higher than those in a deeper area in Figure 6a), bottom currents are not strong enough to disperse them far from the source of erosion. On the middle shelf, the supply of sediment does not appear to be compensated for by erosion and transport, which remain very limited. 
(iii) On the outer shelf, the $90^{\text {th }}$ percentile of BSS is higher than on the middle shelf whereas the wave effect is lower, due to deeper water. The lower fine sediment content can be linked to non negligible south-westward currents which act during periods of on-shore winds (mainly eastern) (Figure 8).

Finally, this study helped explain the main grain-size gradients and to understand the impact of present day hydrodynamics. Such a study may be useful before implementing any sediment transport model, whatever the coastal region, to acquire good knowledge of the modelled BSS statistics. The BSS is the main forcing of a sediment transport model and in this regard a good description of its structure is necessary to satisfactorily analyse the output of a sediment transport model. When the area is microtidal, a good estimation of the variation in BSS requires rather long hydrodynamic simulations. We recommend using a high percentile of the BSS as a proxy for characterizing the sediment forcing, rather than the maximum BSS value, which will be less representative and more dependent on the length and characteristics of the simulation.

Acknowledgements: The authors thank Fabrice Ardhuin, from the French Naval Oceanographic Center (SHOM), who provided the WaveWatch III model implemented for the western Mediterranean Sea. We acknowledge CETMEF and Météo-France for providing the wave data and IRSN (Institut de Radioprotection et de Sûreté Nucléaire), IFREMER (Institut Français de Recherche pour l'Exploitation de la MER), COM (Centre d'Océanologie de Marseille), Agence de l'eau, CEFREM (Centre de Formation et de Recherche sur l'Environnement Marin), CEREGE and LOB Banyuls (Laboratoire d'Océanographie Biologique de Banyuls) for providing grain-size data. We acknowledge the Provence-Alpe-Côte d'Azur Region for their financial support. We thank the anonymous reviewers and the guest editors for their helpful comments and Sabine Charmasson for her attentive review. 


\section{$\underline{\text { Annexes }}$}

\section{A. Validation of the wave model}

Wave simulations were evaluated for significant wave height $\left(H_{s}\right)$, peak period $\left(T_{p}\right)$ and mean period $\left(\mathrm{T}_{\mathrm{m}}\right)$ using the Correlation Coefficient (COR), the Normalized Mean Bias (NMB), the Root Mean Square Error (RMSE) and the Relative Root Mean Square Error also called Scatter Index (SI).

If $x_{i}$ is the measured value at the time step $i, y_{i}$ the simulated value at the same time step, $\bar{x}$ and $\bar{y}$ are respectively the mean values of $\mathrm{x}_{\mathrm{i}}$ and $\mathrm{y}_{\mathrm{i}}$ for the $\mathrm{N}$ time steps, then we have:

$$
\begin{aligned}
& C O R=\frac{\sum_{i=1}^{N}\left(x_{i}-\bar{x}\right)\left(y_{i}-\bar{y}\right)}{\sqrt{\sum_{i=1}^{N}\left(x_{i}-\bar{x}\right)^{2} \sum_{i=1}^{N}\left(y_{i}-\bar{y}\right)^{2}}} \quad S I=\sqrt{\frac{\sum_{i=1}^{N}\left(x_{i}-y_{i}\right)^{2}}{\sum_{i=1}^{N} x_{i}{ }^{2}}} \\
& R M S E=\sqrt{\frac{\sum_{i=1}^{N}\left(x_{i}-y_{i}\right)^{2}}{N}} \quad N M B=\frac{\bar{y}-\bar{x}}{\bar{x}}
\end{aligned}
$$

Validation was performed for two buoys located in the GoL (Figure 1). For the coastal CETMEF buoy (at a depth of about $18 \mathrm{~m}$ ) data were available throughout the year whereas only one month was available for the offshore Météo-France buoy. Comparison of the wave parameters is quite good for the two buoys (Figure 10, Table 1) with an error (SI) of from 17 to $30 \%$ for the wave height. Nevertheless, for all the parameters, the relative error is higher at the coastal location due to the low resolution of the wave model $\left(0.1^{\circ}\right)$.

\section{B. Iterative method of BSS calculation}


The aim is to compute the skin friction component of the total BSS under the influence of waves and currents, which is likely to be affected by the presence of ripples; the latter being dependant on the wave regime.

1/ Computation of physical roughness length scale $\mathrm{k}_{\mathrm{s}}$, which is used to determine the bed roughness $\mathrm{z}_{0}$ for a hypothesized rough turbulent flow $\left(\mathrm{z}_{0}=\mathrm{k}_{\mathrm{s}} / 30\right)$.

$\mathrm{k}_{\mathrm{s}}$ is the maximum of the three degrees of physical roughness, which are:

- grain size roughness: $\mathrm{k}_{\mathrm{sg}}=2.5 \mathrm{D}$

- bedform roughness (Grant and Madsen, 1982): $\mathrm{k}_{\mathrm{sd}}=27.7 \mathrm{H}^{2} / \lambda$

if $\mathrm{H}$ and $\lambda$ are known, if not, initialised with 0 .

- bedload roughness (Wiberg and Rubin, 1989):

$$
k_{s c}=1.1424 D \frac{\tau_{s f}}{\tau_{c}+0.2 \tau_{s f}} \text { if } \tau_{\mathrm{sf}}>\tau_{\mathrm{cr}}
$$

where $\mathrm{D}$ is the average diameter of the grains, $\mathrm{H}$ the height of the ripples, $\lambda$ their wavelength, $\tau_{\mathrm{sf}}$ (initialised with 0 ) the skin friction (whose calculation is specified below), and $\tau_{\mathrm{cr}}$ is the critical shear stress for sediment motion (calculated from Shields parameter, depending on D).

2/ Computation of the total shear stress (from the hydrodynamic point of view) related to waves (index w) and to currents (index c).

$$
\begin{aligned}
& \tau_{c}=\rho u_{*_{c}}^{2} \text { with } u_{*_{c}}=\frac{\kappa u(z)}{\ln \left(z / z_{0}\right)} \\
& \tau_{w}=0.5 \rho f_{w} U_{b}{ }^{2}
\end{aligned}
$$

with (Swart, 1974 ) $\quad \mathrm{f}_{\mathrm{w}}=0.3$ if $\mathrm{A} / \mathrm{k}_{\mathrm{s}}<1.57$, 
where $\rho$ is the density of water, $U_{b}$ is the orbital velocity of the swells on the bottom, $z$ is the height of the first layer above the bottom, $\mathrm{u}(\mathrm{z})$ is the associated speed, $\kappa$ is the Von Karman constant (0.4) and A is the orbital half-excursion near the bottom ( $A=\frac{U_{b} T}{2 \pi}$, T being the wave period).

The formulation of Soulsby (1997) is used to take non-linear wave-current interactions into account

$$
\begin{aligned}
& \tau_{m}=\tau_{c}\left[1+1.2\left(\frac{\tau_{w}}{\tau_{w}+\tau_{c}}\right)^{3.2}\right] \text { and } \\
& \tau_{c w}=\left[\left(\tau_{m}+\tau_{w}|\cos \varphi|\right)^{2}+\left(\tau_{w} \sin \varphi\right)^{2}\right]^{0.5}
\end{aligned}
$$

where $\tau_{\mathrm{m}}$ represents the average shear stress in the current direction, $\tau_{\mathrm{cw}}$ is the maximum shear stress generated during a wave period and $\varphi$ is the angle between the current and wave directions.

3/ Average skin friction computation (Smith and McLean, 1977),

$$
\tau_{s f m}=\frac{\tau_{c w}}{1+\frac{1}{2 \kappa^{2}} C_{D} \frac{H}{\lambda}\left[\ln a\left(\lambda / z_{0 s}\right)^{0.8}\right]^{2}}
$$

with $\mathrm{z}_{0 \mathrm{~s}}=\max \left(\mathrm{k}_{\mathrm{sg}}, \mathrm{k}_{\mathrm{sc}}\right) / 30, \mathrm{C}_{\mathrm{D}}=0.21$ under the hypothesis of a "separate" flow (presence of a eddy downstream from the ripple crest) above the ripples and $\mathrm{a}=0.3$ according to $\mathrm{Li}$ (1994).

At the top of the ripple crests the maximum is reached, and is estimated by Harris and Wiberg (2001)

$\tau_{s f}=\tau_{s f m}(1+8 H / \lambda)$ 
It should be noted that Harris and Wiberg (2001) adopted this expression for the skin frictions over a ripple, but that in any event, the boundary layer model of Smith and McLean (1977) does not take the wave effect into account.

4/ Ripple prediction. The assumption is that ripples are formed only in a non-cohesive environment. The sediment cohesion threshold is fixed at $30 \%$ of mud (Mitchener and Torfs, 1996; Panagiotopoulos et al., 1997). The observations of van der Wal et al. (2005) confirm this hypothesis. Indeed these authors observed significant variations in roughness for mud percentages of less than $30 \%$, and much lower variations when this threshold is exceeded. Moreover, in view of the dynamics of the shelf and in view of the leading role of waves in the sandy areas (cf. § 3.2), the ripples created by the current are not taken into consideration.

The formulations of Soulsby and Whitehouse (2005) are used for the prediction of waveinduced ripples:

If $\tau_{\mathrm{sf}}<\tau_{\mathrm{cr}}, \mathrm{H}$ and $\lambda$ do not evolve

If $\tau_{\mathrm{sf}}>\tau_{\mathrm{cr},} \lambda=\frac{A}{1+0.00187 A / D\left(1-\exp \left\{-(0.0002 A / D)^{1.5}\right\}\right)}$

and $H=0.15 \lambda\left[1-\exp \left(-(5000 D / A)^{3.5}\right)\right]$

The above equations implicitly take into account the "sheet-flow" through the D/A parameter, which involves destruction of the ripples when it decreases too strongly.

If the sediment is cohesive, the BSS is calculated by carrying out only step 2 with a fixed $z_{0}$.

$5 /$ Test of convergence on $\tau_{\mathrm{sf}}$. The procedure is repeated from step $1 /$ until convergence. 


\section{Comparison of methods of calculation}

BSS values calculated with the previously described method were compared with those calculated with the reference method (with a fixed $z_{0}$ ) for the year 2001 (Figure 11). In the coastal area (10 m depth) current-induced BSS is not very sensitive to the presence of ripples. The presence of ripples tends to increase waves-induced BSS during low energy periods. During high energy periods (Figure 11, framed area), the induced "sheet-flow", which destroys the ripples, causes a major reduction in wave-induced BSS. A slight reduction also occurs in the current-induced BSS when "sheet-flow" intervenes during episodes of strong currents (framed area).

The result thus highlights the need to take into account the modification of the micro topography of the bottom and its influence on the skin friction component of the total BSS.

\section{$\underline{\text { References }}$}

Albérola, C., and C. Millot, 2003. Circulation in the French Mediterranean coastal zone near Marseilles: the influence of wind and the Northern Current. Continental Shelf Research 23, 587-610.

Aloisi, J.-C., 1986. Sur un modèle de sédimentation deltaique. Contribution à la connaissance des marges passives. These d'Etat, Université de Perpignan.

André, G., P. Garreau, and P. Fraunié, this issue. Mesoscale slope current variability in the Gulf of Lions. Interpretation of in-situ measurements using a tridimensional model. Continental Shelf Research

André, G., P. Garreau, V. Garnier, and P. Fraunié, 2005. Modelled variability of the sea surface circulation in the North-western Mediterranean Sea and in the Gulf of Lions. Ocean Dynamics 55, 294-308.

Ardhuin, F., L. Bertotti, J.-R. Bidlot, L. Cavaleri, V. Filipetto, J.-M. Lefevre, and P. Wittmann, 2007. Comparison of wind and wave measurements and models in the Western Mediterranean Sea. Ocean Engineering 34 (3-4), 526-541.

Bassetti, M.A., G. Jouet, F. Dufois, S. Berne, M. Rabineau, and M. Taviani, 2006. Sand bodies at the shelf edge in the Gulf of Lions (Western Mediterranean): Deglacial history and modern processes. Marine Geology 234 (1-4, EUROSTRATAFORM VOL. 1: Source to Sink Sedimentation on the European Margin), 93-109.

Berné, S., G. Lericolais, T. Marsset, J.F. Bourillet, and M. de Batist, 1998. Erosional shelf sand ridges and lowstand shorefaces. Example from tide and wave dominated environments of France. J. Sediment. Res. 68, 540-555.

Blumberg, A.F., and G.L. Mellor, 1987. A description of a three dimensional coastal circulation model. In: Heap, N.S. (Ed.), Three dimensional coastal ocean models, Coastal and Estuarine Sciences 4, American Geophysical Union, Washington, D.C, $1-16$. 
Bourrin, F., and X. Durrieu de Madron, 2006. Contribution to the study of coastal rivers and associated prodeltas to sediment supply in the Gulf of Lions (N-W Mediterranean Sea). Vie \& Milieu / Life \& Environment 56 (4), 307-314.

Bourrin, F., P.L. Friend, C.L. Amos, X. Durrieu de Madron, C.E.L. Thompson, E. Manca, and C. Ulses, this issue. An 0ceanic Flood in a microtidal, Storm dominated basin: the Têt, Gulf of Lions (NW Mediterranean, France). Continental Shelf Research

Canals, M., P. Puig, X. Durrieu de Madron, S. Heussner, A. Palanques, and J. Fabres, 2006. Flushing submarine canyons. Nature 444 (354-357)

Chu, P.C., Y. Qi, Y. Chen, P. Shi, and Q. Mao, 2004. South China sea wind-wave characteristics. Part I: validation of Wavewatch III using TOPEX/Poseidon data. Journal of atmospheric and oceanic technology 21, 1718-1733.

Crepon, M., and C. Richez, 1982. Transient Upwelling Generated by Two-Dimensional Atmospheric Forcing and Variability in the Coastline. Journal of Physical Oceanography 12 (12), 1437-1457.

Drake, D.E., and D. Cacchione, 1985. Seasonnal variation in sediment transport on the Russian River shelf, California. Continental Shelf Research 4, 495-514.

Dufau-Julliand, C., P. Marsaleix, A. Petrenko, and I. Dekeyser, 2004. Three-dimensional modeling of the Gulf of Lion's hydrodynamics (northwest Mediterranean) during January 1999 (MOOGLI3 experiment) and late winter 1999: Western Mediterranean Intermediate Water's (WIW's) formation and its cascading over the shelf break. Journal of Geophysical Research 109, C11002.

Dyer, K.R., 1980. Velocity profiles over a ripples bed and the threshold of movement of sand. Estuarine Coastal Mar. Sci. 10, 181-199.

Estournel, C., X. Durrieu de Madron, P. Marsaleix, F. Auclair, C. Julliand, and R. Vehil, 2003. Observations and modelisation of the winter coastal oceanic circulation in the Gulf of Lions under wind conditions influenced by the continental orography (FETCH experiment). Journal of Geophysical Research 108 (C3), 1-18.

Ferre, B., X. Durrieu de Madron, C. Estournel, C. Ulses, and G. Le Corre, this issue. Impact of natural (waves and currents) and anthropogenic (trawl) resuspension on the export of particulate matter to the open ocean. Application to the Gulf of Lion (NW Mediterranean). Continental Shelf Research

Ferre, B., K. Guizien, X. Durrieu de Madron, A. Palanques, J. Guillen, and A. Gremare, 2005. Fine-grained sediment dynamics during a strong storm event in the inner-shelf of the Gulf of Lion (NW Mediterranean). Continental Shelf Research 25 (19-20, Impact of Natural and Trawling Events on Resuspension, dispersion and fate of POLlutants (INTERPOL)), 2410-2427.

Flexas, M.M., X. Durrieu de Madron, M.A. Garcia, M. Canals, and P. Arnau, 2002. Flow variability in the Gulf of Lions during the MATER HFF experiment (March-May 1997). Journal of Marine Systems 33-34, 197-214.

Gatti, J., A. Petrenko, J.-L. Devenon, Y. Leredde, and C. Ulses, 2006. The Rhone river dilution zone present in the northeastern shelf of the Gulf of Lion in December 2003. Continental Shelf Research 26 (15), 1794-1805.

Got, H., and J.C. Aloisi, 1990. The Holocene sedimentation on the Gulf of Lions margin: a quantitative approach. Continental Shelf Research 10 (9-11), 841-855.

Grant, W.D., and O.S. Madsen, 1982. Movable bed roughness in unsteady oscillatory flow. Journal of Geophysical Research 87 (C1), 469-481.

Guarracino, M., B. Barnier, P. Marsaleix, X. Durrieu de Madron, A. Monaco, K. Escoubeyrou, and J.-C. Marty, 2006. Transfer of particulate matter from the northwestern Mediterranean continental margin: Variability and controlling factors. Journal of Marine Research 64, 195-220.

Guillén, J., F. Bourrin, A. Palanques, X. Durrieu de Madron, P. Puig, and R. Buscail, 2006. Sediment dynamics during wet and dry storm events on the Tet inner shelf (SW Gulf of Lions). Marine Geology 234 (1-4, EUROSTRATAFORM VOL. 1: Source to Sink Sedimentation on the European Margin), 129-142. 
Guillén, J., J. Jiménez, A. Palanques, V. Gracia, P. Puig, and A. Sanchez-Arcilla, 2002. Sediment resuspension across a microtidal, low-energy shelf. Continental Shelf Research $22(2)$

Harris, C.K., and P.L. Wiberg, 2001. A two-dimensional, time-dependent model of suspended sediment transport and bed reworking for continental shelves. Computers \& Geosciences 27 (6), 675-690.

Harris, C.K., and P.L. Wiberg, 2002. Across-shelf sediment transport: Interactions between suspended sediment and bed sediment. Journal of Geophysical Research 107 (C1), 81.

Heussner, S., X. Durrieu de Madron, A. Calafat, M. Canals, J. Carbonne, N. Delsaut, and G. Saragoni, 2006. Spatial and temporal variability of downward particle fluxes on a continental slope: Lessons from an 8-yr experiment in the Gulf of Lions (NW Mediterranean). Marine Geology 234 (1-4, EUROSTRATAFORM VOL. 1: Source to Sink Sedimentation on the European Margin), 63-92.

Langlais, C., 2007. Etude de la variabilité interannuelle des échanges côte-large: simulation haute résolution de la dynamique du Golfe du Lion. Phd thesis, University of Toulon.

Lansard, B., S. Charmasson, C. Gasco, M.P. Anton, C. Grenz, and M. Arnaud, 2007. Spatial and temporal variations of plutonium isotopes (238Pu and $239,240 \mathrm{Pu})$ in sediments off the Rhone River mouth (NW Mediterranean). Science of The Total Environment $376(1-3), 215-227$.

Lazure, P., and F. Dumas, 2007. An external-internal mode coupling for a 3D hydrodynamical Model for Applications at Regional Scale (MARS3D). Advances in water Ressources doi:10.1016/j.advwatres.2007.06.010

Le Hir, P., P. Cann, B. Waeles, H. Jestin, and P. Bassoulet, in press. Erodibility of natural sediments: experiments on sand/mud mixtures from laboratory and field erosion tests. Sediment and Ecohydraulics: INTERCOH 2005 Chapter 11

Leendertse, J.J., 1970. A water-quality simulation model for well-mixed estuaries and coastal seas. Principle of Computation, The Rand Corporation 1 (RM-6230)

Leonard, B.P., 1979. A stable and accurate convective modelling procedure based on quadratic upstream interpolation. Comp. Methods Appl. Mech. Eng. 19, 59-98.

Li, M.Z., 1994. Direct skin friction measurements and stress partitioning over movable sand ripples. Journal of Geophysical Research 99 (C1), 791-799.

Lyne, V.D., B. Butman, and W.D. Grant, 1990. Sediment movement along the US East coast continental shelf, II. Modelling suspended sediment concentration during storms. Continental Shelf Research 10, 429-460.

Millot, C., 1990. The Gulf of Lions' hydrodynamics. Continental Shelf Research 10 (9-11), 885-894.

Millot, C., and M. Crepon, 1981. Inertial oscillations on the continental shelf of the Gulf of Lions. Observations and theory. Journal of Physical Oceanography 11 (5), 639-657.

Miralles, J., M. Arnaud, O. Radakovitch, C. Marion, and X. Cagnat, 2006. Radionuclide deposition in the Rhone River Prodelta (NW Mediterranean sea) in response to the December 2003 extreme flood. Marine Geology 234 (1-4, EUROSTRATAFORM VOL. 1: Source to Sink Sedimentation on the European Margin), 179-189.

Miralles, J., O. Radakovitch, and J.-C. Aloisi, 2005. 210Pb sedimentation rates from the Northwestern Mediterranean margin. Marine Geology 216 (3), 155-167.

Mitchener, H., and H. Torfs, 1996. Erosion of mud/sand mixtures. Coastal Engineering 29, 125.

Monaco, A., 1971. Contribution à l'étude géologique et sédimentologique du plateau continental du Roussillon. Phd thesis, University of Perpignan.

Pacanowsky, R.C., and S.G.H. Philander, 1981. Parameterization of the vertical mixing in the numerical models of tropical oceans. Journal of Physical Oceanography 11, 14431451.

Palanques, A., X. Durrieu de Madron, P. Puig, J. Fabres, J. Guillen, A. Calafat, M. Canals, S. Heussner, and J. Bonnin, 2006. Suspended sediment fluxes and transport processes in the Gulf of Lions submarine canyons. The role of storms and dense water cascading. 
Marine Geology 234 (1-4, EUROSTRATAFORM VOL. 1: Source to Sink

Sedimentation on the European Margin), 43-61.

Palanques, A., P. Puig, J. Guillén, J. Jiménez, V. Gracia, A. Sanchez-Arcilla, and O. Madsen, 2002. Near-bottom suspended sediment fluxes on the microtidal low-energy Ebro continental shelf (NW Mediterranean). Continental Shelf Research 22, 285-303.

Panagiotopoulos, I., G. Voulgaris, and M.B. Collins, 1997. The influence of clay on the threshold of movement of fine sandy beds. Coastal Engineering 32, 19-43.

Partheniades, E., 1962, A study of erosion and deposition of cohesive soils in salt water

$\mathrm{Ph}$.D. thesis., University of California, Berkeley, 182pp.

Petrenko, A., 2003. Variability of circulation features in the Gulf of Lion NW Mediterranean Sea. Importance of inertial currents. Oceanologica Acta 26 (4), 323-338.

Petrenko, A., Y. Leredde, and P. Marsaleix, 2005. Circulation in a stratified and wind-forced Gulf of Lions, NW Mediterranean Sea: in situ and modeling data. Continental Shelf Research 25 (1), 7-27.

Puig, P., A. Palanques, and J. Guillén, 2001. Near-bottom suspended sediment variability caused by storms and near-inertial waves on the ebro mid continental shelf. Marine Geology 178, 81-93.

Roussiez, V., J.-C. Aloisi, A. Monaco, and W. Ludwig, 2005a. Early muddy deposits along the Gulf of Lions shoreline: A key for a better understanding of land-to-sea transfer of sediments and associated pollutant fluxes. Marine Geology 222-223 (Mediterranean Prodelta Systems), 345-358.

Roussiez, V., W. Ludwig, A. Monaco, J.-L. Probst, I. Bouloubassi, R. Buscail, and G. Saragoni, 2006. Sources and sinks of sediment-bound contaminants in the Gulf of Lions (NW Mediterranean Sea): A multi-tracer approach. Continental Shelf Research 26 (16), 1843-1857.

Roussiez, V., W. Ludwig, J.-L. Probst, and A. Monaco, 2005b. Background levels of heavy metals in surficial sediments of the Gulf of Lions (NW Mediterranean): An approach based on 133Cs normalization and lead isotope measurements. Environmental Pollution 138 (1), 167-177.

Schaaff, E., 2003. Dynamique de la matière particulaire à l'interface eau-sédiment en zone côtière : approches expérimentales et modélisation. Phd thesis, université de la Méditerranée. Aix-Marseille II.

Schaaff, E., C. Grenz, and C. Pinazo, 2002. Erosion of particulate inorganic and organic matter in the Gulf of Lion. Comptes Rendus Geoscience 334 (15), 1071-1077.

Smagorinsky, J., 1963. General circulation experiments with the primitive equations.1-The basic experiment. Monthly Weather Review 91, 99-165.

Smith, J.D., and S.R. McLean, 1977. Spatially averaged flow over a wavy surface. Journal of Geophysical Research 82 (12), 1735-1746.

Soulsby, R.L., 1997. Dynamics of marine sands. A manual for practical applications. 249 pp., Thomas Telford, London.

Soulsby, R.L., and R.J.S. Whitehouse, 2005, Prediction of ripple properties in shelf seas. Mark 2 predictor for time evolution, HR Wallingford Report TR 154.

Swart, D.H., 1974. Offshore sediment transport and equilibrium beach profiles. Delft Hydraulics Laboratory publication 131

The Medatlas Group: Gaillard, P., P. Ravazzola, C. Kontolios, L. Arrivet, G.A. Athanassoulis, C.N. Stefanakos, T.P. Gerostathis, L. Cavaleri, L. Bertotti, M. Sclavo, E. Ramieri, L. Dentone, C. Noel, C. Viala, and J.M. Lefevre, 2004, Wind and Wave Atlas of the Mediterranean Sea, pp. 420.

Tolman, H.L., 2002a. User manual and system documentation of WAVEWATCH-III version 2.22. Tech. report 222, NOAA/NWS/NCEP/MMAB.

Tolman, H.L., 2002b, Validation of WAVEWATCH-III. in version 1.15, NOAA/NWS/NCEP/MMAB.

Ulses, C., 2006. Dynamique océanique et transport de la matière particulaire dans le Golfe du Lion : Crue, tempête et période hivernale. Phd thesis, Université Paul Sabatier, Toulouse. 
Ulses, C., C. Estournel, J. Bonnin, X. Durrieu de Madron, and P. Marsaleix, in press. Interactions between storms and dense water cascading on shelf-slope exchange in the Gulf of Lion (NW Mediterranean). Journal of Geophysical Research

Ulses, C., C. Estournel, X. Durrieu de Madron, and A. Palanques, this issue. Suspended Sediment Transport in the Gulf of Lion (NW Mediterranean): Impact of Extreme Storms and Floods. Continental Shelf Research

van der Wal, D., P.M.J. Herman, and A. Wielemaker-van den Dool, 2005. Characterisation of surface roughness and sediment texture of intertidal flats using ERS SAR imagery. Remote Sensing of Environment 98, 96-109.

Whitehouse, R., R.L. Soulsby, W. Roberts, and H. Mitchener, 2000. Dynamics of estuarine muds. 210 pp., Thomas Telford, London.

Wiberg, P.L., D.E. Drake, and D. Cacchione, 1994. Sediment re-suspension and bedarmoring during high bottom stress events on the northern California inner continental shelf: measurements and predictions. Continental Shelf Research 14, 1191-1220.

Wiberg, P.L., and D.M. Rubin, 1989. Bed roughness produced by saltating sediment. Journal of Geophysical Research 94, 5011-5016.

\section{Figure captions}

Figure 1: Study area, main characteristics of the circulation (redrawn from Millot (1990)). Isobaths $20,50,90,160,500,1000$ and $2000 \mathrm{~m}$ are plotted. Positions of the wave buoys Météo-France 61002 and CETMEF 01301 are shown.

Figure 2: (a) Surficial fraction of sand $(>63 \mu \mathrm{m})$ on the shelf based on new experimental observations. (b) Surficial non-pelitic fraction $(>40 \mu \mathrm{m})$ on the shelf redrawn from CEFREM data acquired from 1970 to 1990 . Isobaths $30,50,100$ and $160 \mathrm{~m}$ are plotted.

Figure 3: Probability of occurrence of wind direction (direction the wind comes from) (a), wind intensity (b), wave direction (direction the wave comes from) (c) and wave height (d) at position $42^{\circ} \mathrm{N}, 5^{\circ} \mathrm{E}$. Black histograms correspond to year 2001 and white histograms correspond to WW-MEDATLAS climatology. For wind intensity and wave height, the increase in the frequency of higher values is due to the fact that the intervals are not homogenous and may be subject to sudden variation. 
Figure 4: $90^{\text {th }}$ percentile of wave- and current-induced BSS $\left(\mathrm{N} \cdot \mathrm{m}^{-2}\right)$ from numerical modelling.

Figure 5: Mean respective contributions of waves and currents to the BSS greater than the $90^{\text {th }}$ percentile. Isobaths $30,50,100$ and $160 \mathrm{~m}$ are plotted. The circle corresponds to point $\mathrm{C}$.

Figure 6: Polar diagrams at point $\mathrm{C}\left(3.88^{\circ} \mathrm{E} 42.86^{\circ} \mathrm{N}\right)$. (a) Wave-induced BSS $\left(\mathrm{N} . \mathrm{m}^{-2}\right)$ as a function of the mean wave direction (direction the wave comes from). Data values smaller than $10^{-6}$ are not drawn. (b) Wave-induced BSS $\left(\mathrm{N} \cdot \mathrm{m}^{-2}\right)$ as a function of wind direction (direction the wind comes from). (c) Wind stress intensity on the surface $\left(\mathrm{N} \cdot \mathrm{m}^{-2}\right)$ as a function of wind direction. (d) Current-induced BSS $\left(\mathrm{N} \cdot \mathrm{m}^{-2}\right)$ as a function of wind direction. The biggest dot on Figures (c) and (d) corresponds to the same event. Note that only Figure (a) depends on wave direction and is based on logarithmic scale.

Figure 7: Mean vector (arrows) of current-induced BSS during onshore wind events (left) and during offshore winds events (right). Only the wind episodes greater than $5 \mathrm{~m} \cdot \mathrm{s}^{-1}$ occurring in 2001 have been considered. The grey scale corresponds to the fraction between the intensity of the mean vector and the mean BSS intensity noted R.

Figure 8: Origin of current-induced BSS. Probability (\%) of having simultaneously, a BSS higher than $0.04 \mathrm{~N} \cdot \mathrm{m}^{-2}$ and on-shore winds (direction from $45^{\circ}$ to $225^{\circ}$ ). Inside the blue line (resp. red line) the iso-probability $\tau_{\mathrm{c}}>0.04 \mathrm{~N} . \mathrm{m}^{-2}$ exceeds $1 \%$ (resp. $0.2 \%$ ). White areas correspond to $0 \%$ probability. Isobath $160 \mathrm{~m}$ (slope) is shown. Locations $\mathrm{A}, \mathrm{B}, \mathrm{C}$ are discussed in the text.

Figure 9: Polar diagram of current-induced BSS $\left(\mathrm{N} . \mathrm{m}^{-2}\right)$ as a function of their direction (direction the current flows) at various points on the shelf (cf. green circles Figure 8). A: in front of Petit Rhone (position $4.3^{\circ} \mathrm{E} 43.4^{\circ} \mathrm{N}, 29 \mathrm{~m}$ depth), B: in front of Leucate (position 
$3.1^{\circ} \mathrm{E} 42.9^{\circ} \mathrm{N}, 31 \mathrm{~m}$ depth), $\mathrm{C}$ : outer shelf (position $3.88^{\circ} \mathrm{E} 42.86^{\circ} \mathrm{N}, 100 \mathrm{~m}$ depth). In red, onshore wind events, in blue, continental wind events, and in black, frictions lower than $0.02 \mathrm{~N} . \mathrm{m}^{-2}$. All the events that occurred in 2001 (one every 3 hours) are represented.

Figure 10: Comparison of $\mathrm{H}_{\mathrm{s}}$ and $\mathrm{T}_{\mathrm{p}}$ between WAVEWATCH-III and the Météo-France 61002 buoy.

Figure 11: Time variation of current-induced BSS $\left(\tau_{c}\right)$ (upper graph) and wave-induced BSS $\left(\tau_{\mathrm{w}}\right)$ (middle graph) at a fixed location in the GoL. BSS calculated with the reference method is plotted in dotted line whereas that calculated with the described method are plotted in full line. In the lower graph, $\mathrm{H}_{\mathrm{s}}(\mathrm{m})$ is plotted in full line and height of the ripples $(\mathrm{cm})$ in dotted line.

\section{Table caption}

Table 1: Statistical parameters for the model validation on Météo-France 61002 buoy and on Cetmef 01301 buoy. 


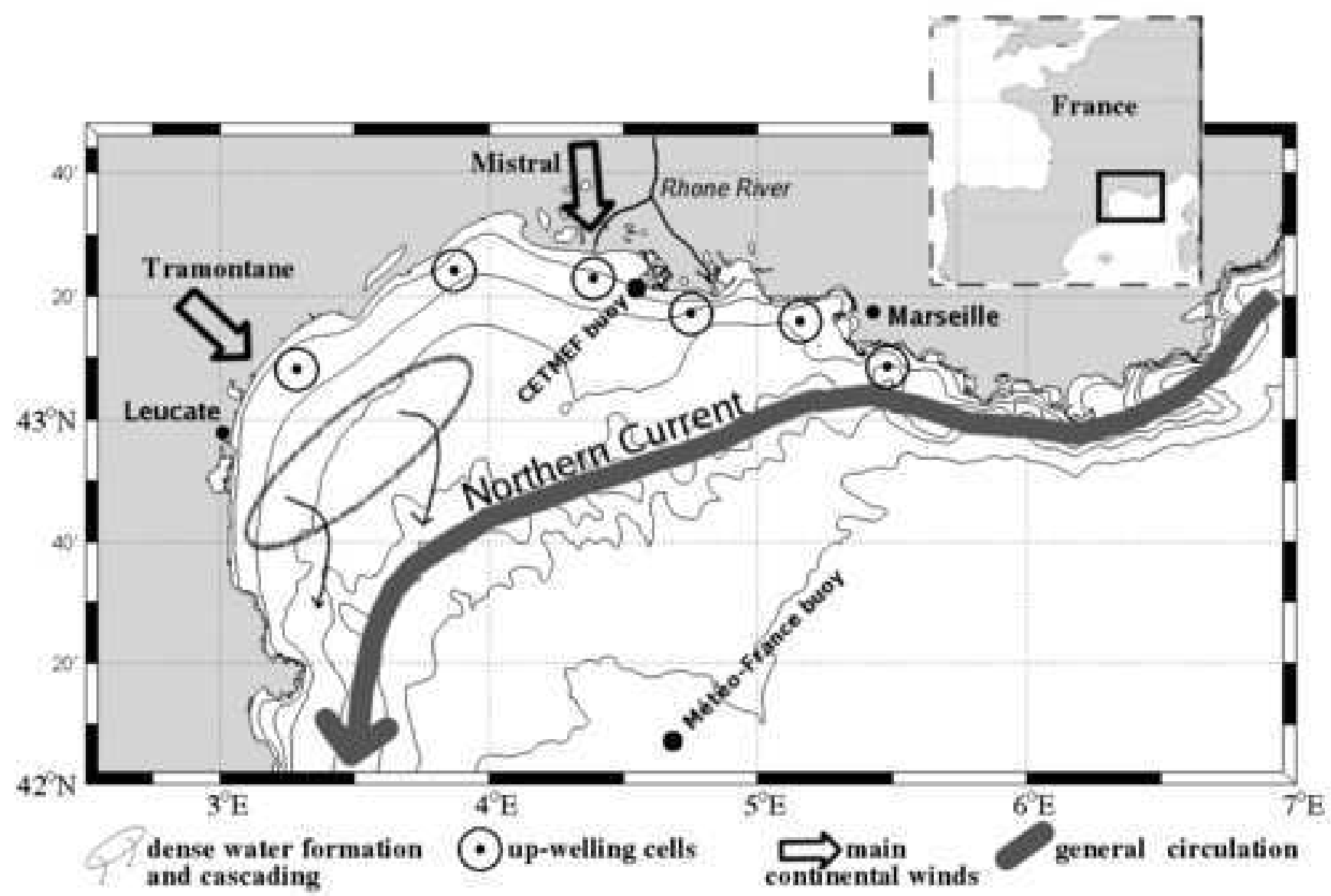


Elick here to download high resolution image

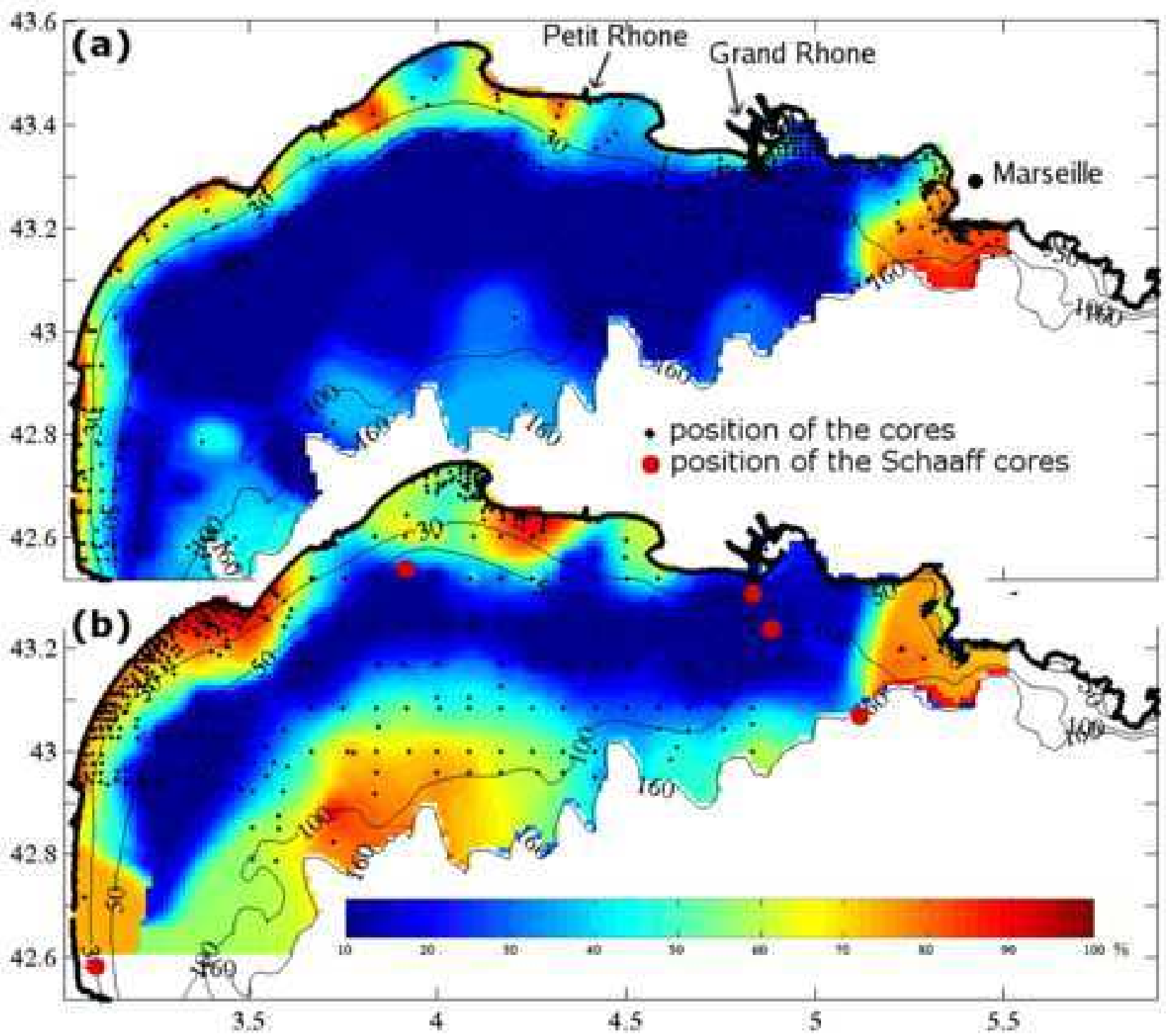



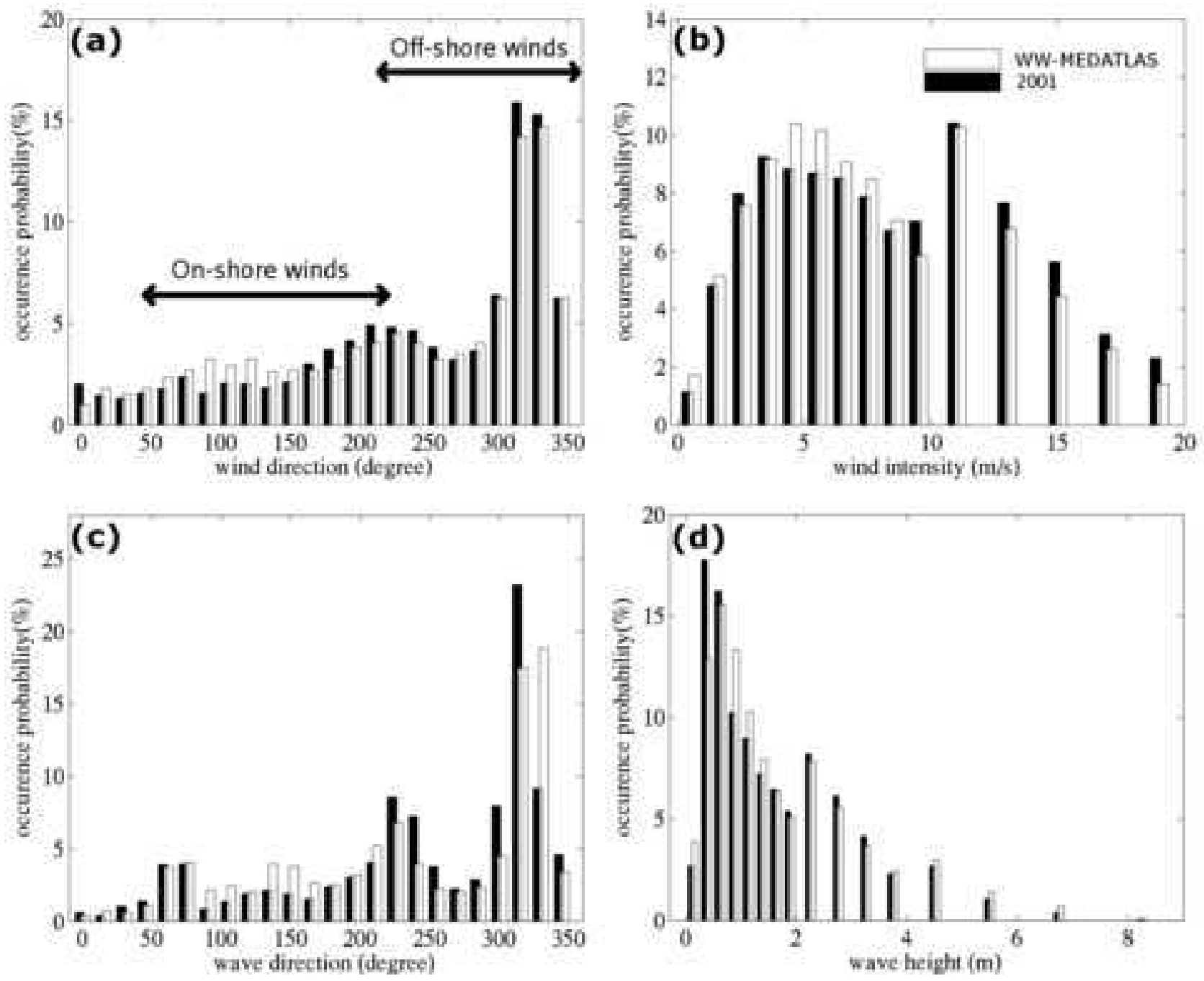
Elick here to download high resolution image

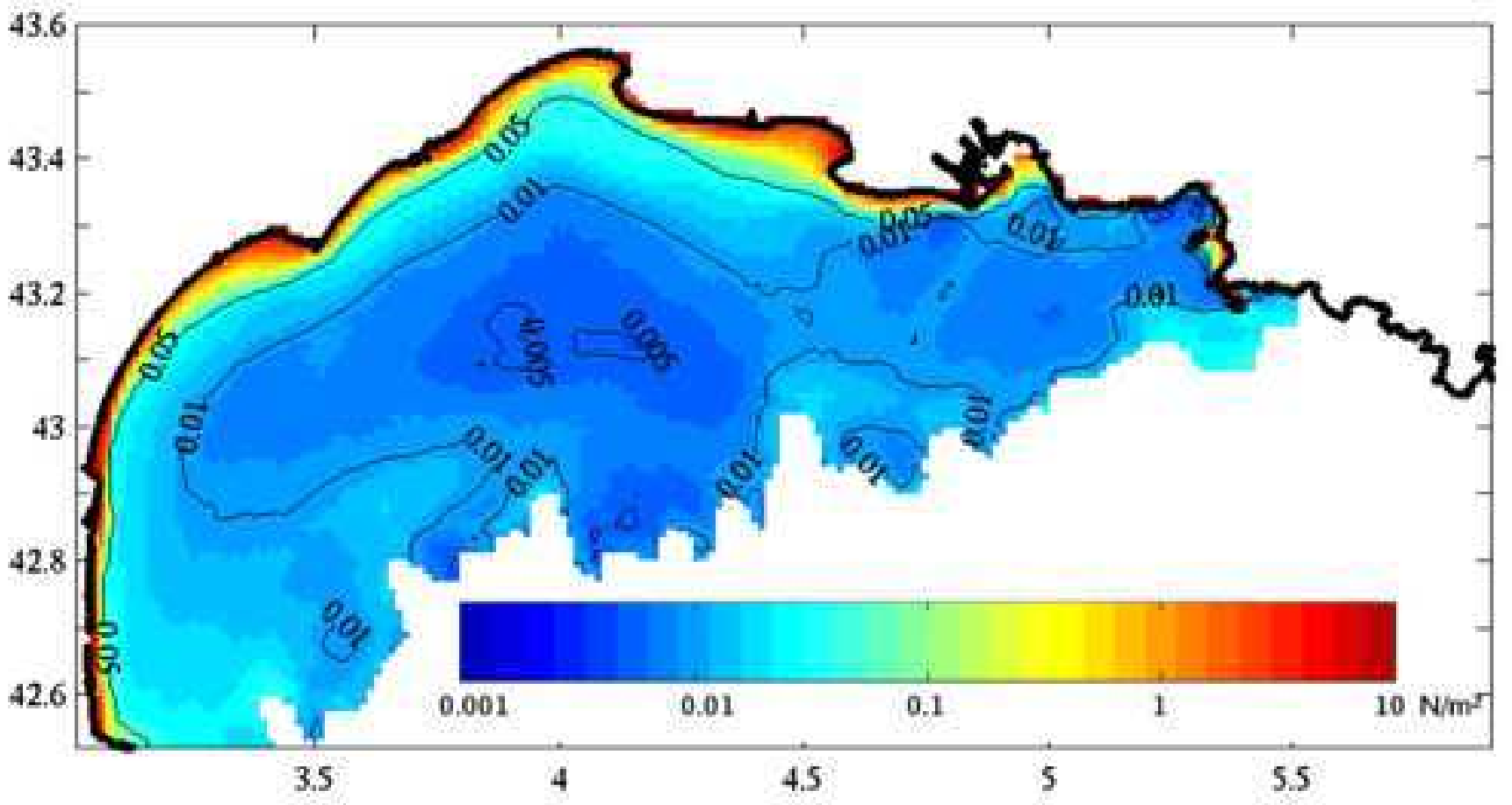


igure 5

Click here to download high resolution image

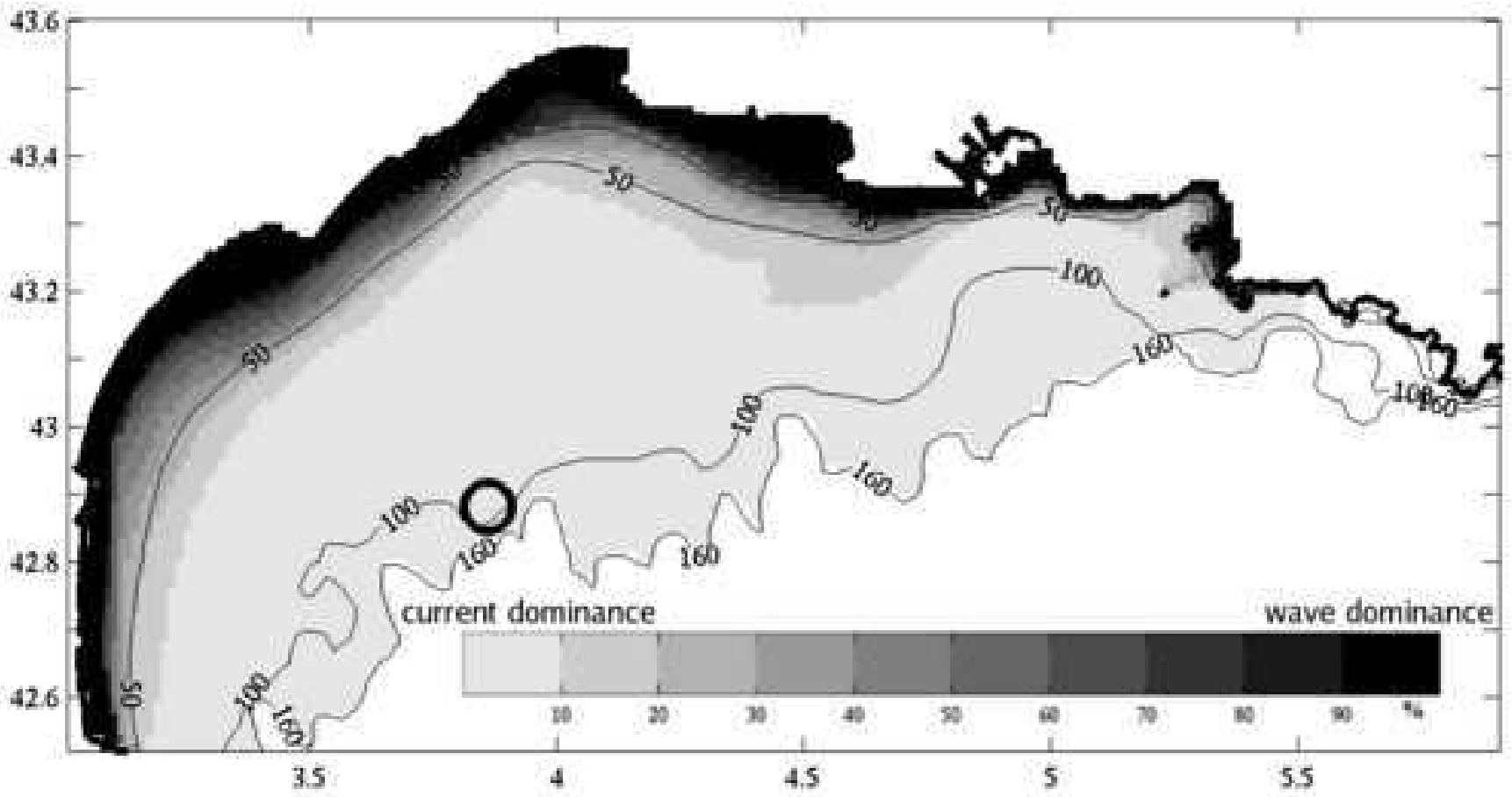



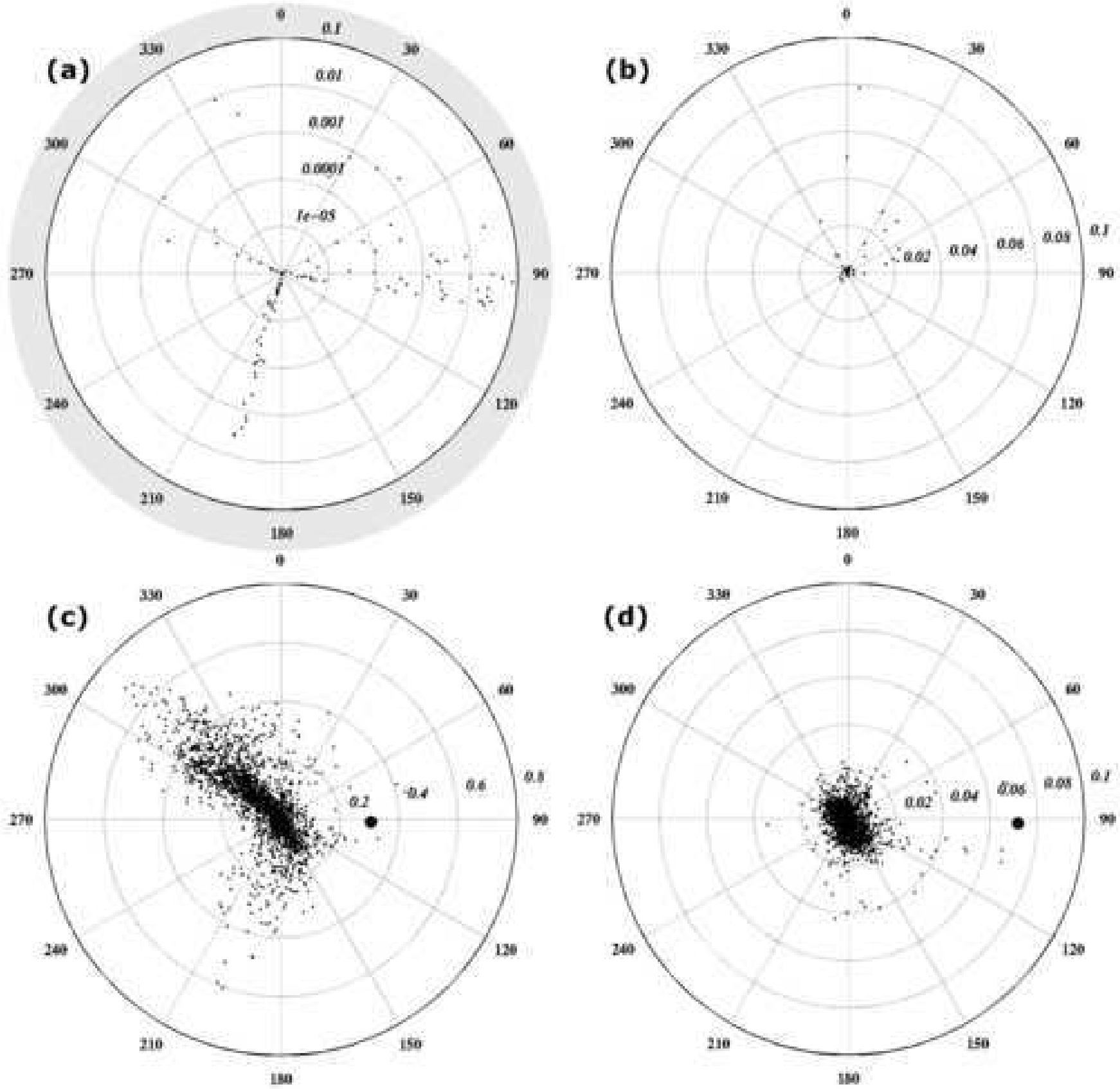


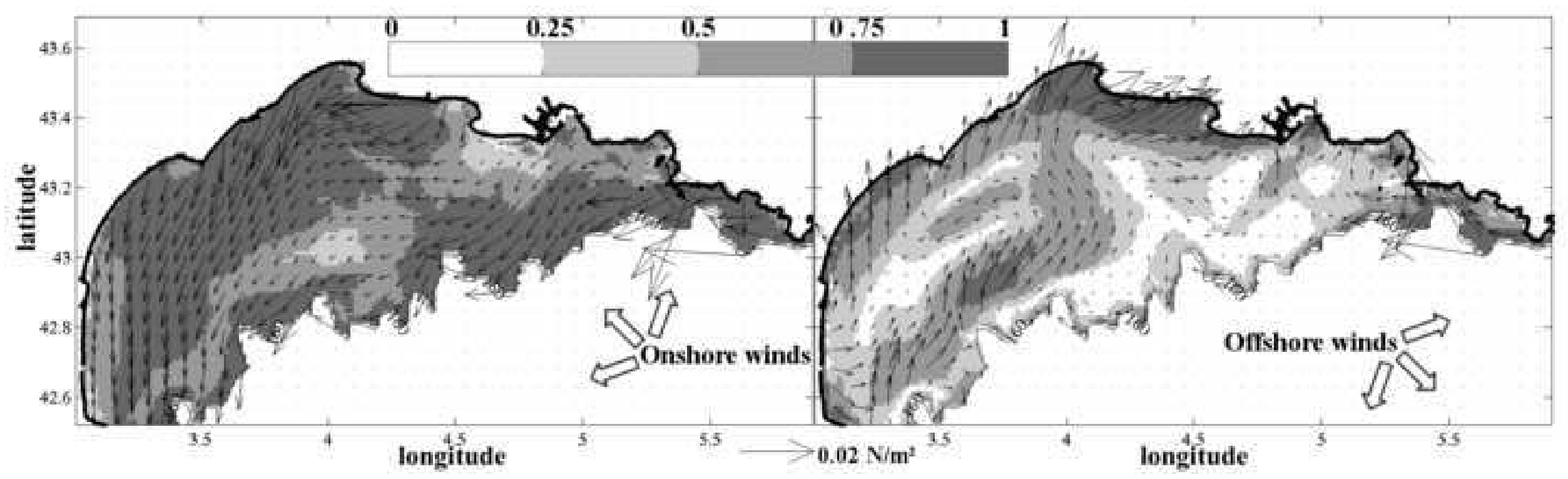




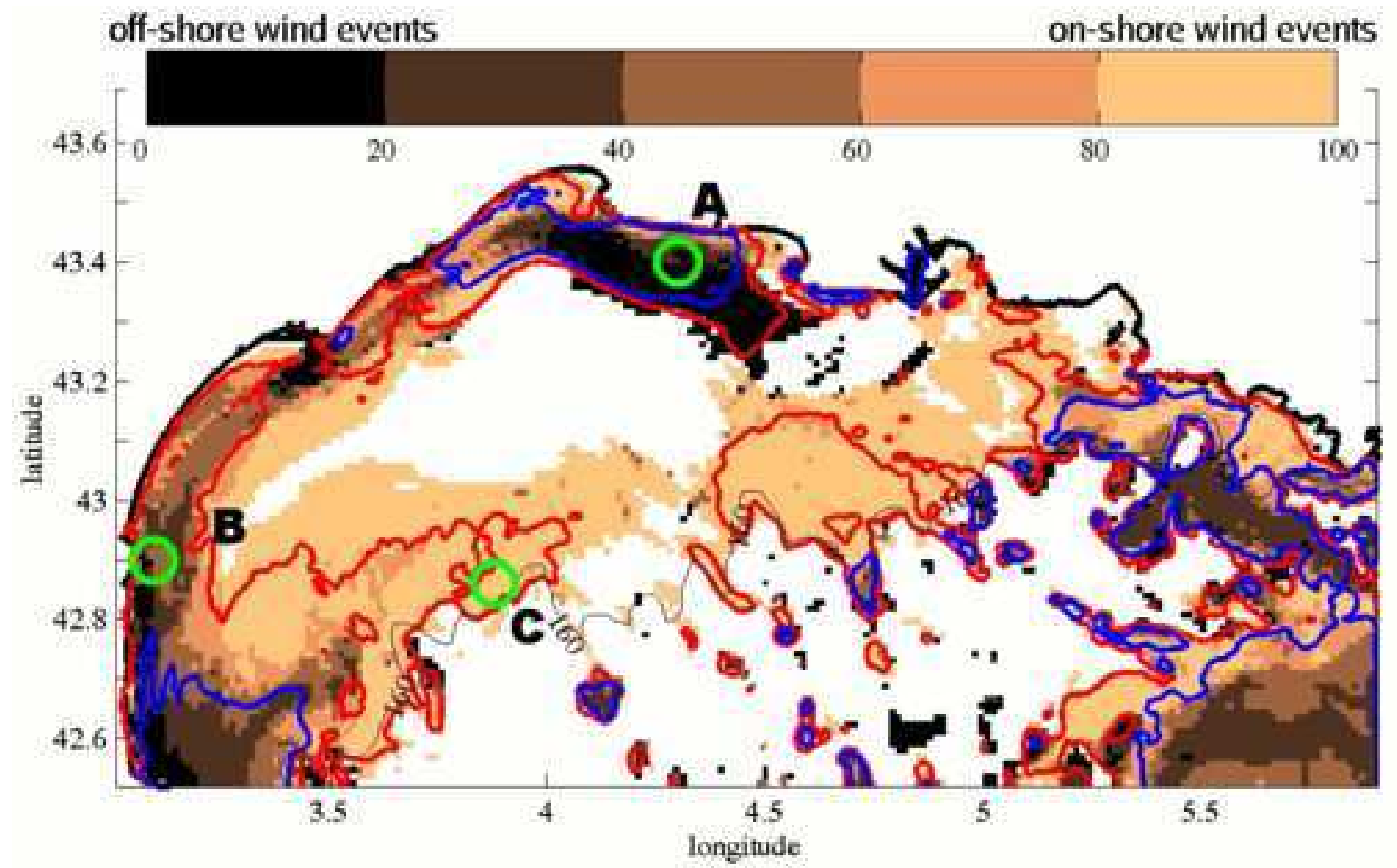


igure 9

Click here to download high resolution image
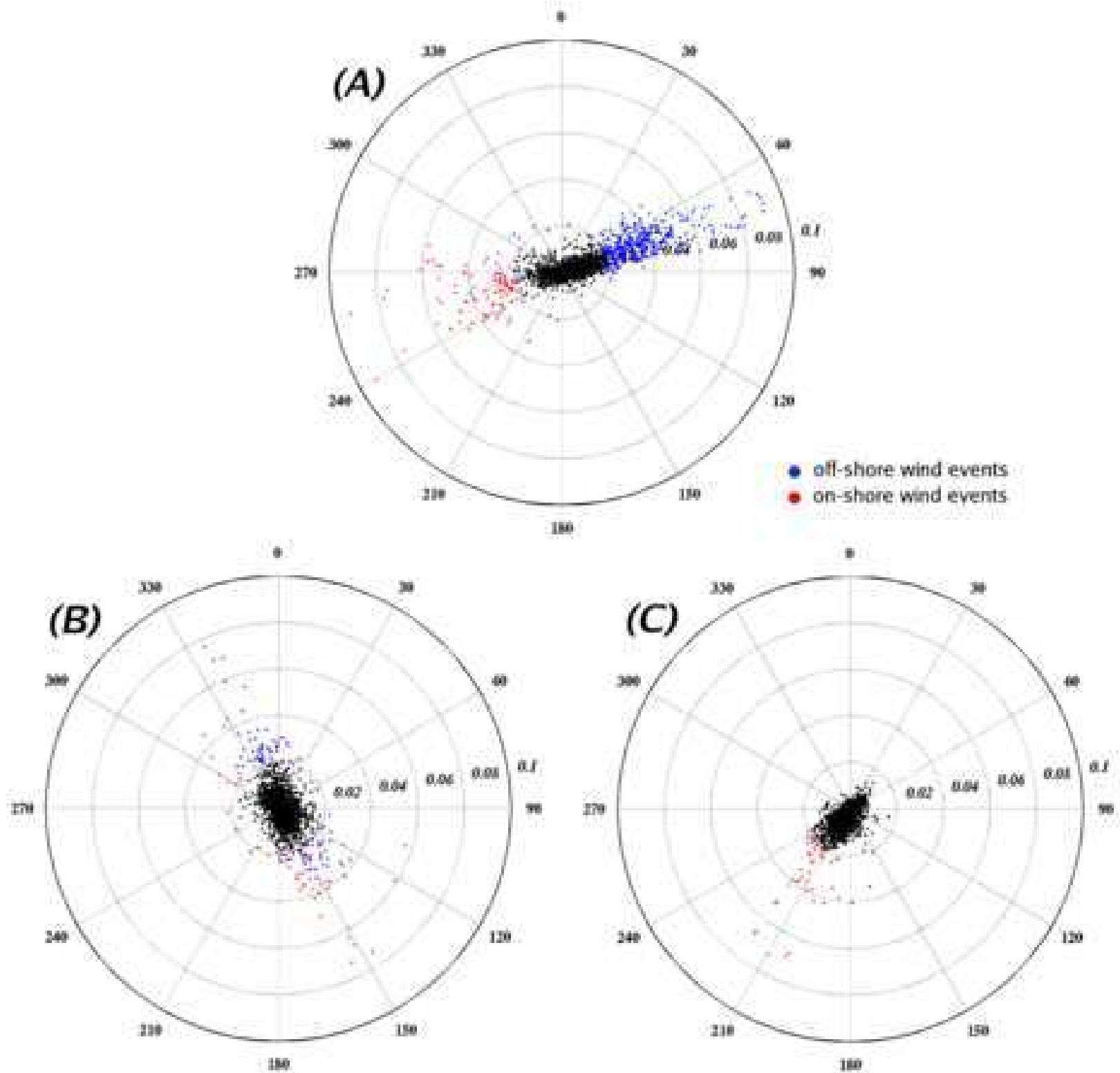
lick here to download high resolution image
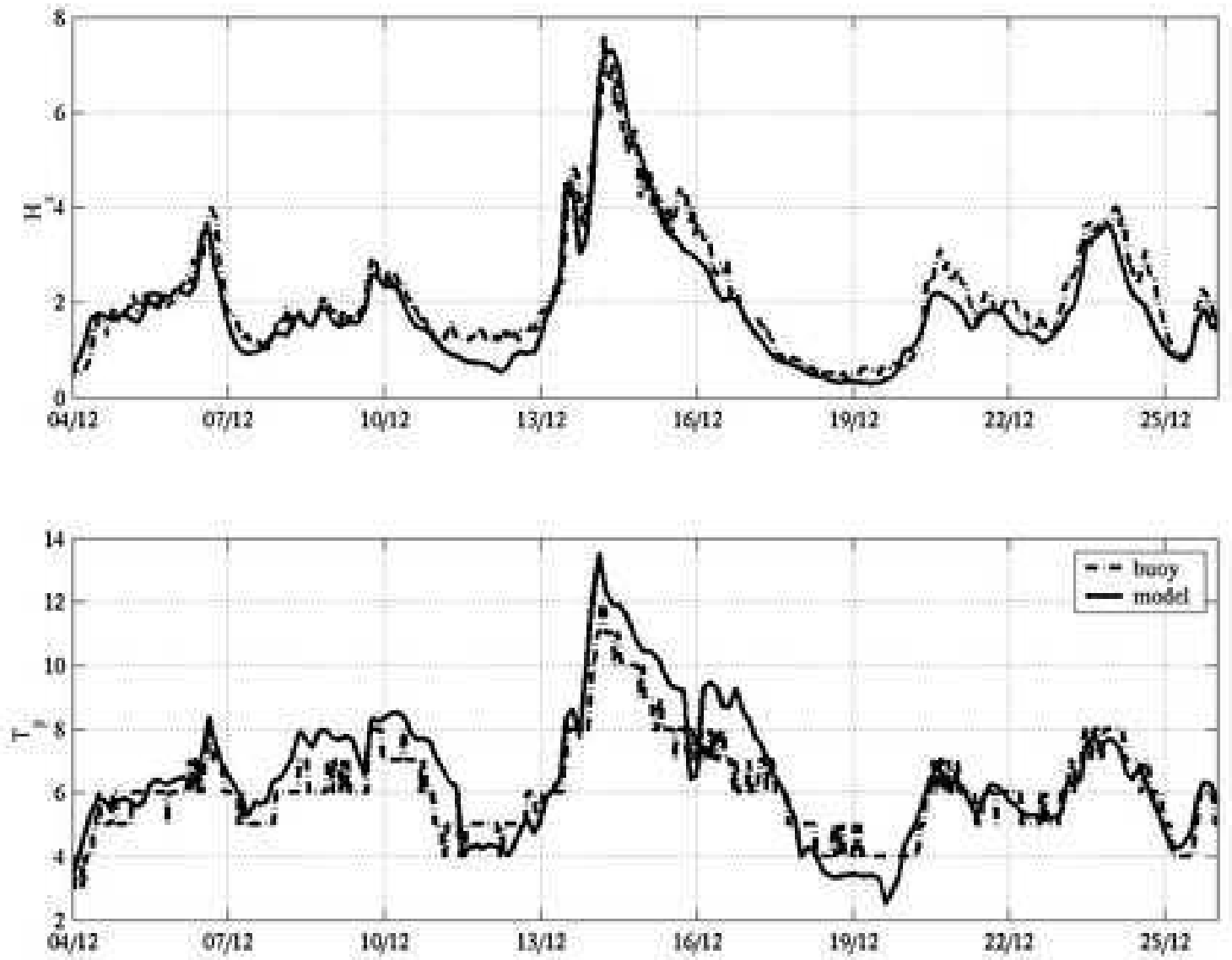
lick here to download high resolution image

Position $=4,3 * \mathrm{E}, 43,44 * \mathrm{~N}$, Deput : $9.7138 \mathrm{~m}$
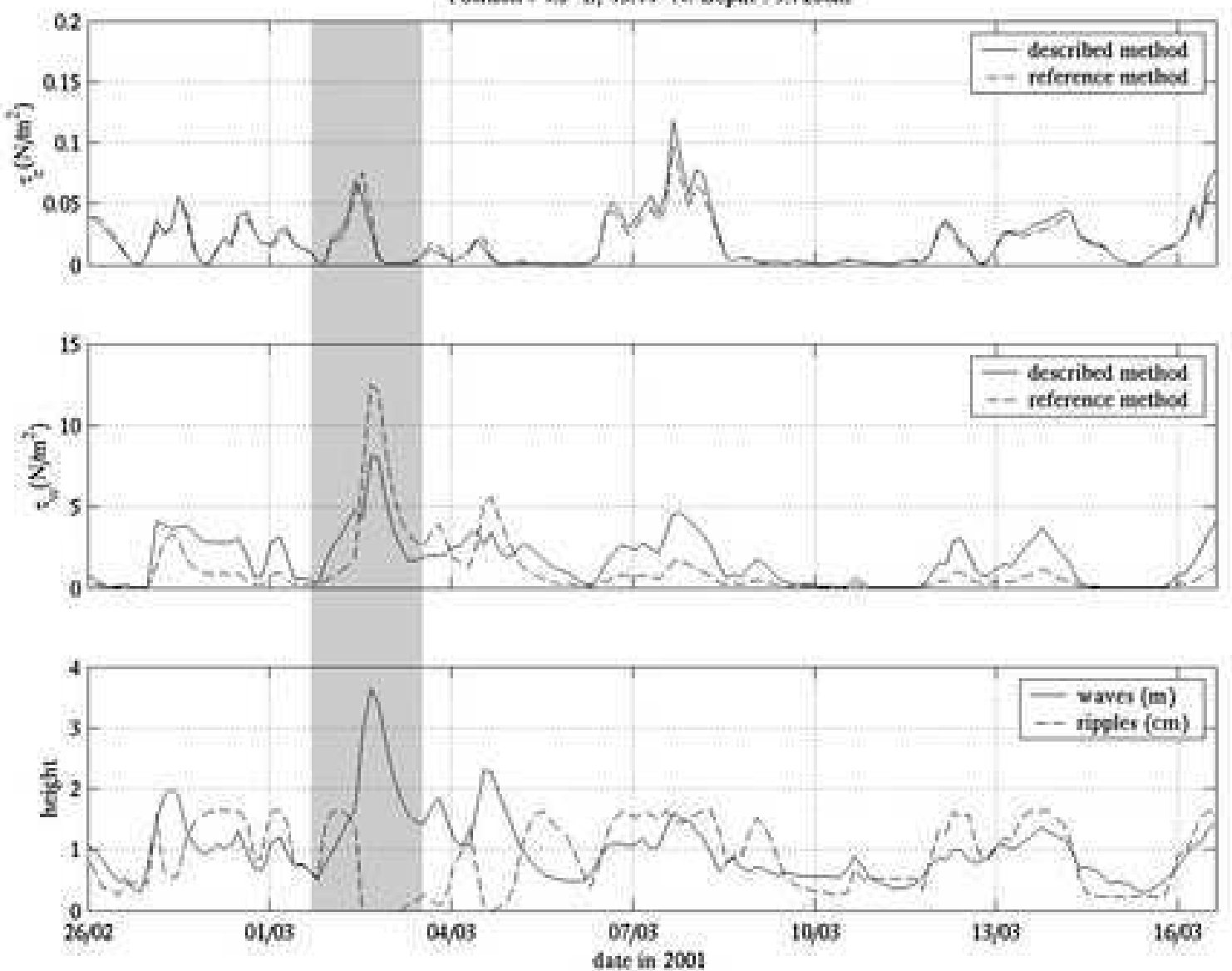


\begin{tabular}{|c|c|c|c|c|c|}
\cline { 3 - 6 } \multicolumn{2}{c|}{} & COR & NMB & RMSE & $S I$ \\
\hline \multirow{3}{*}{$\begin{array}{c}\text { Météo-France } \\
\text { buoy }\end{array}$} & $H_{s}$ & 0.96 & -0.11 & 0.43 & 0.17 \\
\cline { 2 - 6 } & $T_{p}$ & 0.9 & 0.06 & 0.99 & 0.16 \\
\hline \multirow{3}{*}{ CETMEF buoy } & $H_{s}$ & 0.82 & -0.15 & 0.28 & 0.3 \\
\cline { 2 - 6 } & $T_{p}$ & 0.38 & -0.24 & 2.1 & 0.38 \\
\cline { 2 - 6 } & $T_{m}$ & 0.67 & -0.10 & 0.9 & 0.2 \\
\hline
\end{tabular}

